\title{
Luminescent $\operatorname{Re}(\mathrm{I}) / \mathrm{Au}(\mathrm{I})$ Species As Selective Anticancer Agents for HeLa Cells
}

\author{
Andrés Luengo, Marta Redrado, Isabel Marzo, Vanesa Fernández-Moreira,* \\ and M. Concepción Gimeno*
}

Cite This: https://dx.doi.org/10.1021/acs.inorgchem.0c00813

Read Online

ACCESS

Џll Metrics \& More

四国 Article Recommendations

S1 Supporting Information

ABSTRACT: A series of neutral and cationic heterotrimetallic complexes of the type $f a c-\left[\operatorname{Re}(\mathrm{CO})_{3}\left(\operatorname{bipy}(\mathrm{CC})_{2}-(\mathrm{AuL})_{2}\right) \mathrm{X}\right]^{n}$, where bipy $(\mathrm{CC})_{2}$ is 4,4'-alkynyl-2,2' -bipyridine; $\mathrm{L}$ is either triphenylphosphine $\left(\mathrm{PPh}_{3}\right),[1,3-$ bis(2,6-diisopropylphenyl)-imidazol-2-ylidene] (IPr), or tert-butyl isocyanide $\left(\mathrm{CN}^{t} \mathrm{Bu}\right)$; and $\mathrm{X}$ is a chloride $(n=0)$ or acetonitrile $(n=1)$, were synthesized and characterized together with their $\operatorname{Re}(\mathrm{I})$ precursors, i.e., fac- $\left[\operatorname{Re}(\mathrm{CO})_{3}\left(\text { bipy }(\mathrm{CC})_{2}\right) \mathrm{X}\right]^{n}$. X-ray diffraction of complexes $\mathbf{1}, \mathbf{3}$, and $\mathbf{6}$ corroborated the expected octahedral and linear distribution of the ligands along the $\operatorname{Re}(\mathrm{I})$ and $\mathrm{Au}(\mathrm{I})$ centers, respectively. Luminescent studies showed that all the complexes displayed a broad emission band centered

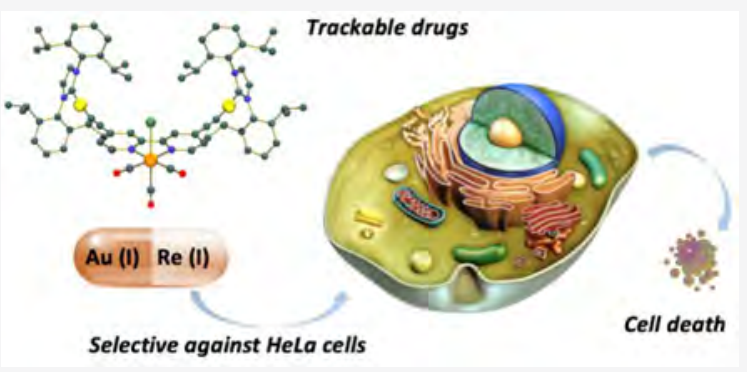
between 565 and $680 \mathrm{~nm}$, corresponding to a ${ }^{3} \mathrm{MLCT}$ from the $\operatorname{Re}(\mathrm{I})$ to the diimine derivative. The presence of the gold fragment coordinated to the diimine ligand shifted in all cases the emission maxima toward higher energies. Such an emission difference could be potentially used for assessing the precise moment of interaction of the probe with the biological target if the gold fragment is implicated. Antiproliferative studies in cancer cells, A549 (lung cancer) and HeLa (cervix cancer), showed a generalized selectivity toward HeLa cells for those heterotrimetallic species incubated at longer times ( 72 vs $24 \mathrm{~h}$ ). ICP-MS spectrometry revealed the greater cell internalization of cationic vs neutral species. Preliminary fluorescence microscopy experiments showed a different behavior of the complexes in HeLa and A549 cell lines. Whereas the complexes in A549 were randomly distributed in the outside of the cell, those incubated with HeLa cells were located close to the cellular membrane, suggesting some type of interaction, and possibly explaining their cellular selectivity when it comes to the antiproliferative activity displayed in the different cell lines.

\section{INTRODUCTION}

Molecular imaging is becoming one of the most important techniques within the development of novel treatments in medicine. ${ }^{1}$ This technique involves a noninvasive study of the biological processes in vivo at a cellular level, rendering highly precise information. The key role would be the design of imaging agents that, combined with drugs, make them visible, quantifiable, and traceable over time. In this way, the development and optimization of specific treatments would be easier and more effective. Within this framework, the design of luminescent and bioactive heterometallic complexes offers a clear advantage over monometallic or organic molecules. ${ }^{2}$ It can be hypothesized that the inherent properties of each metallic fragment are prone to be modulated separately. Later, when both fragments are combined, a synergistic effect would be expected to take place, possibly intensifying their therapeutic and traceability potential. In this particular regard, luminescent $\mathrm{d}^{6}$ metal complexes combined with bioactive $\mathrm{Au}(\mathrm{I})$ or $\mathrm{Ru}(\mathrm{II})$ species, analogues to Auranofin or RAPTA, respectively, ${ }^{3}$ or just mimicking the coordination sphere of a specific drug, have been demonstrated to fulfill the require- ment for becoming traceable luminescent and bioactive species, see Figure 1.4

In general, the use of luminescent $\mathrm{d}^{6}$ metal complexes in cell imaging $^{5}$ presents several advantages such as high photostability that renders high robustness to reach the biological targets intact. Additionally, they have long-lived phosphorescence that allows time-resolved detection, and their large Stokes shifts do not allow self-quenching mechanisms to take place. Both features improve the signal/noise ratio and as a consequence deliver greater image resolution. In the specific case of $\operatorname{Re}(\mathrm{I})$ complexes, the typical emissive structures are those derived from $f a c-\left[\operatorname{Re}\left(\mathrm{N}^{\wedge} \mathrm{N}\right)(\mathrm{CO})_{3}(\mathrm{~L})\right]^{0 /+}$, where $\mathrm{N}^{\wedge} \mathrm{N}$ represents a diimine ligand and $\mathrm{L}$ a halogen or a $\mathrm{N}$-donor ligand. The emissive behavior is normally attributed to a metalto-ligand-charge transfer ( $\left.{ }^{3} \mathrm{MLCT}\right)$ transition, where the

Received: March 17, 2020 

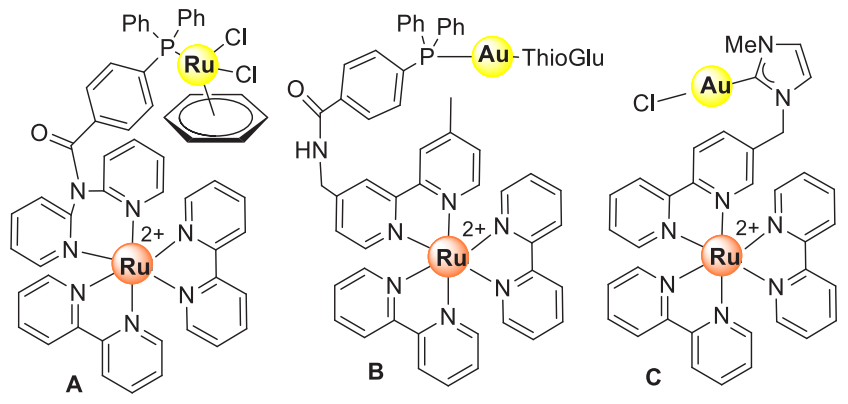

Figure 1. Examples of luminescent bioactive heterobimetallic species. $^{3,4}$

orbital of the diimine ligand is the main ligand contributor. ${ }^{6}$ In addition, in the recent years some rhenium tricarbonyl species have also showed antiproliferative potential in a wide range of tumor cancer cell lines, ${ }^{7}$ which could be used as a great input in the design of novel metallic drugs. Different combinations of $\operatorname{Re}(\mathrm{I}) / \mathrm{Au}(\mathrm{I})$ complexes have been described in the literature as promising candidates for trackable anticancer drugs. Figure 2 shows some examples of heterometallic fac-[Re(bipy)-

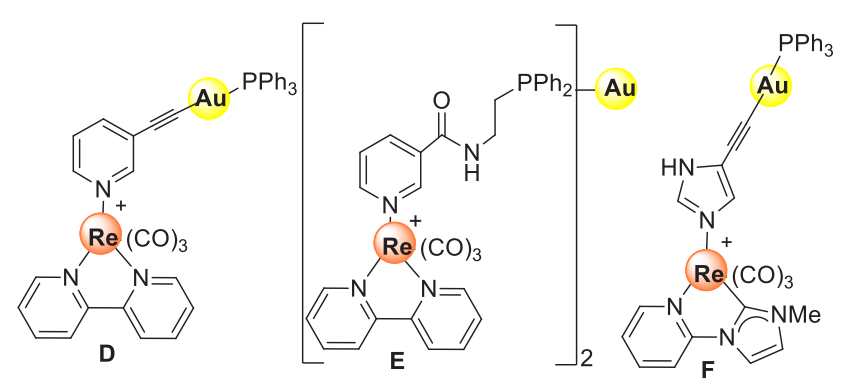

Figure 2. Examples of $\operatorname{Re}(\mathrm{I}) / \mathrm{Au}(\mathrm{I})$ species. $^{8,9}$

$\left.(\mathrm{CO})_{3}\left(\mathrm{~L}-\mathrm{AuPPh} \mathrm{P}_{3}\right)\right]^{+}$complexes, where an imidazole derivative or an alkynyl-pyridine derivative was used as a linker between both metallic fragments. ${ }^{8}$ These heterobimetallic complexes were proven to bear good cytotoxicity against A549 lung cancer cells coming almost exclusively from the bioactive $\mathrm{Au}(\mathrm{I})$ fragment. Also some analogues derived from $[(\mathrm{fac}-$ $\left[\operatorname{Re}(\right.$ bipy $\left.\left.\left.)(\mathrm{CO})_{3}(\mathrm{~L})\right]\right)_{2} \mathrm{Au}\right]^{3+}$ where $\mathrm{L}$ is a ditopic $\mathrm{P}, \mathrm{N}$-donor ligand have shown their suitability as trackable bioactive species. In all cases, the $f a c-\left\{\operatorname{Re}(\right.$ bipy $\left.)(C O)_{3}\right\}$ core was providing the traceability potential. ${ }^{9}$

In the search for the ultimate probe, it would be groundbreaking to be able to detect the precise moment of the interaction with the biological target. For doing so, a clear change of the emissive properties of the luminescent tag would be ideal. Such a change could be achieved if the interaction with the biological target directly affects the emissive orbitals of the luminescent tag. In the case of relying on $\operatorname{Re}(\mathrm{I})$ derivatives for the traceability, a wise approach would be to introduce the bioactive fragment within the diimine ligand, whose orbitals are the main ligand orbitals implicated in the emissive transition, i.e., ${ }^{3}$ MLCT. Therefore, it can be expected that once the complex reaches the biological target and the chemical transformation occurs between the bioactive fragment and the biological target, the emission would be clearly modified. The information obtained from this interaction could be used later to structurally refine the bioprobe in order to maximize the therapeutic potential. Thus, this work aims to develop the first heterotrimetallic probes able to expose precisely the right time of reaching and/or interacting with the biological target.

\section{RESULTS AND DISCUSSION}

Synthesis and Characterization. Selected bioactive $\mathrm{Au}(\mathrm{I})$ fragments will be directly grafted onto the diimine ligand of species derived from $f a c-\left[\operatorname{Re}\left(\mathrm{L}_{\mathrm{NN}}\right)(\mathrm{CO})_{3}(\mathrm{~L})\right]^{0 /+}$ to allow detecting the precise moment of interaction of the probe with the biological target.

In this context, 4,4'-dialkynyl-2,2'-bipyridine $\left(\mathbf{L}_{\mathrm{NN}}\right)$ was chosen as the linker ligand between both metal fragments. Thus, $\mathbf{L}_{\mathbf{N N}}$ allows a direct electronic communication between both metals and any modification within the bioactive gold fragment, either disconnection from the luminescent tag (the $\operatorname{Re}(\mathrm{I})$ fragment) or replacement of the gold ancillary ligand for a biomolecule or any other residue will directly have a quantitative effect on the luminescence.

Starting from the $4,4^{\prime}$-dibromo-2,2' -bipyridine and following the same procedure described by Grosshenny and coworkers, ${ }^{10} \mathbf{L}_{\mathrm{NN}}$ was synthesized, see Scheme 1. After that,

Scheme 1. Schematic Synthetic Route for the Preparation of $\mathrm{L}_{\mathrm{NN}}$ and the Rhenium and Gold Complexes $1-4^{a}$
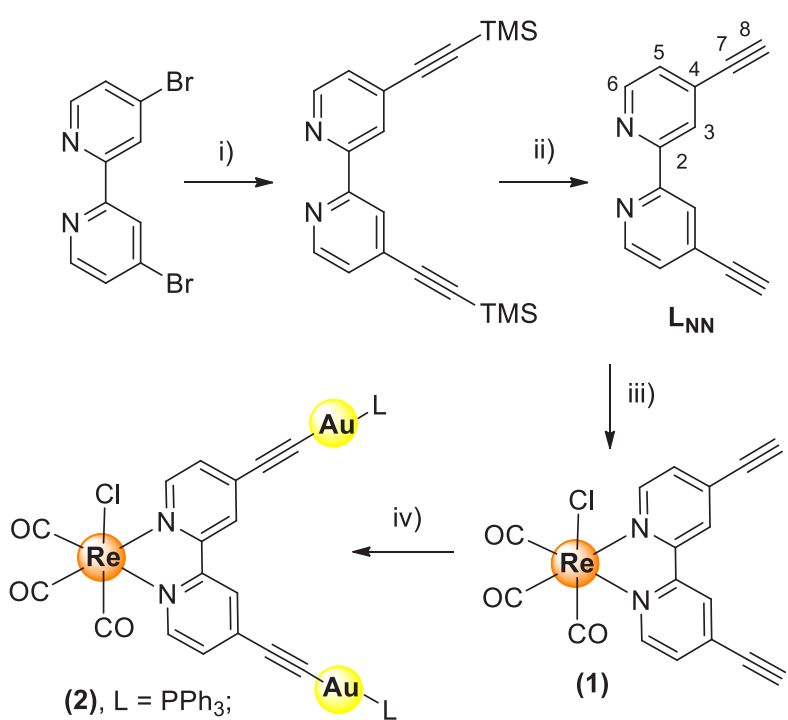

(3), $L=I \operatorname{Pr} ;(4), L=C N^{t} B u$

${ }^{a}$ (i) TMSA, [Pd( $\left.\left.\mathrm{PPh}_{3}\right)_{2} \mathrm{Cl}_{2}\right], \mathrm{CuI}$, DIPEA, THF; (ii) KF, MeOH; (iii) $\left[\mathrm{Re}(\mathrm{CO})_{5} \mathrm{Cl}\right]$, toluene, $80{ }^{\circ} \mathrm{C}, 8 \mathrm{~h}$; (iv) $\left[\mathrm{Au}(\mathrm{acac})\left(\mathrm{PPh}_{3}\right)\right]$, $\mathrm{DCM}, \mathrm{rt}, 3 \mathrm{~h}$ or $[\mathrm{AuCl}(\mathrm{IPr})], \mathrm{KOH}, \mathrm{MeOH}, \mathrm{rt}, 24 \mathrm{~h}$ or $\left[\mathrm{Au}\left(\mathrm{CN}^{t} \mathrm{Bu}\right) \mathrm{Cl}\right], \mathrm{KOH}, \mathrm{MeOH}, \mathrm{rt}, 1$ night.

the $\operatorname{Re}(\mathrm{I})$ complex 1 was obtained by heating together stoichiometric amounts of $\mathbf{L}_{\mathrm{NN}}$ and $\left[\mathrm{Re}(\mathrm{CO})_{5} \mathrm{Cl}\right]$ in methanol. Subsequent additions of the different gold(I) substrates, either $\left[\mathrm{Au}(\mathrm{acac})\left(\mathrm{PPh}_{3}\right)\right]$ in dichloromethane or the respective chloride gold derivatives of 1,3-bis(2,6-diisopropylphenyl)imidazol-2-ylidene (IPr) and tert-buthylisocyanide $\mathrm{CN}^{t} \mathrm{Bu}$ in the presence of a base in methanol, delivered the expected neutral heterotrimetallic complexes $2-4$ respectively, see Scheme 1.

At this point, the poor solubility of complexes 2-4 was already evident, which represents a serious drawback when it comes to test these species for biological applications. Therefore, the synthesis of the corresponding cationic 
complexes was attempted by treatment of the chloride complexes 2-4 with silver triflate in acetonitrile, Scheme 2,

Scheme 2. Schematic Synthetic Procedure and Depiction of Final Complexes $(5,6 \text {, and } 7)^{a}$

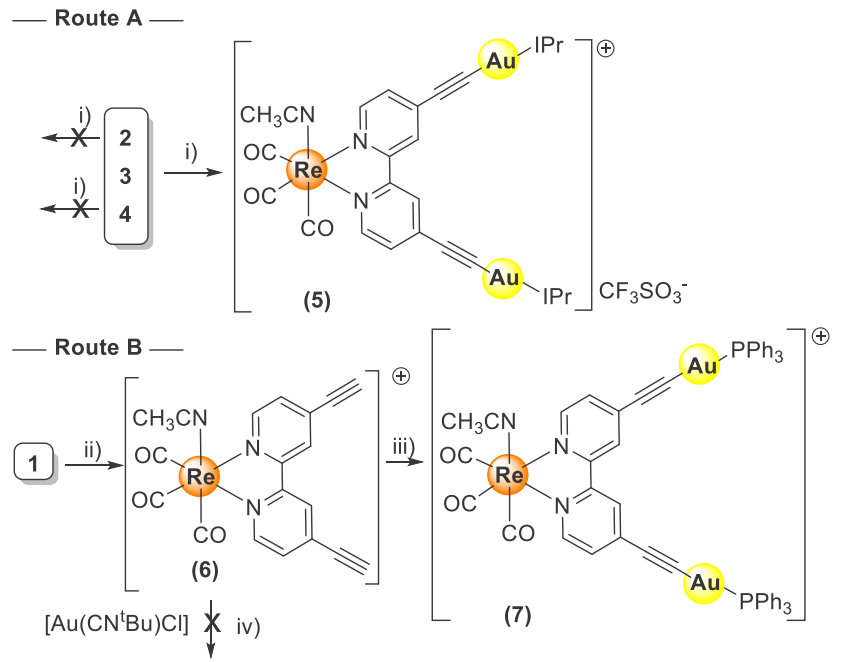

(1)

${ }^{a}$ (i) AgOTf, $\mathrm{CH}_{3} \mathrm{CN}, 40{ }^{\circ} \mathrm{C}, 1$ night; (ii) AgOTf, $\mathrm{CH}_{3} \mathrm{CN}, 65^{\circ} \mathrm{C}, 1$ night; (iii) $\left[\mathrm{Au}(\mathrm{acac})\left(\mathrm{PPh}_{3}\right)\right], \mathrm{CH}_{3} \mathrm{CN}, \mathrm{rt}, 3 \mathrm{~h}$; (iv) $\left[\mathrm{Au}\left(\mathrm{CN}^{\mathrm{t}} \mathrm{Bu}\right) \mathrm{Cl}\right.$, $\mathrm{KOH}, \mathrm{MeOH}$, rt.

route $\mathrm{A}$. In this way, the axial chloride ligand can be removed as insoluble $\mathrm{AgCl}$ and a molecule of solvent $\left(\mathrm{CH}_{3} \mathrm{CN}\right)$ will be coordinated to the rhenium metal center instead. Despite several attempts with species $\mathbf{2 - 4}$, only in the case of complex 3 does the removal of the chloride and insertion of acetonitrile succeed, leading to the formation of complex 5. Conversely, the same reaction with complexes $\mathbf{2}$ and $\mathbf{4}$ afforded highly insoluble solids which could not be characterized. It is known that alkynyl gold complexes in the presence of a silver salt can afford highly insoluble polymers by coordination of the silver center to the alkynyl ligand and also establishing metallophilic interactions with the gold metals. ${ }^{11}$ A similar explanation could be thought of in the present case. The lesser steric hindrance of $\mathrm{PPh}_{3}$ and $\mathrm{CN}^{t} \mathrm{Bu}$ in comparison with that of the IPr ligand does not prevent the polymerization reaction to take place. Alternatively, a different strategy was considered for the preparation of the cationic compound derived from species 2 and 4 , route $B$, Scheme 2 . The abstraction of the chloride was performed on the rhenium precursor 1 , rendering the cationic species 6. Then, coordination of the gold fragment was performed using the same conditions described before in Scheme 1 when complexes $\mathbf{2}$ and $\mathbf{4}$ were delivered, i.e., $\left[\mathrm{Au}(\mathrm{acac})\left(\mathrm{PPh}_{3}\right)\right]$ and $\left[\mathrm{Au}\left(\mathrm{CN}^{t} \mathrm{Bu}\right) \mathrm{Cl}\right]$ as gold reactants, respectively. Unfortunately, only compound 7 was obtained. This time the handicap was the presence of a chloride ligand within the gold starting material, $\left[\mathrm{Au}\left(\mathrm{CN}^{\mathrm{t}} \mathrm{Bu}\right) \mathrm{Cl}\right]$. Complex 6 is highly sensitive to the presence of chloride ligands in the reaction media and compound $\mathbf{1}$ was obtained systematically, Scheme 2, route $B$.

Then, eventually, four neutral (species 1-4) and three cationic (5-7) metallic complexes were synthesized, five of them being heterotrimetallic $\operatorname{Re}(\mathrm{I}) / \mathrm{Au}(\mathrm{I})$ species $(2-5$ and 7 ) and two monometallic $\operatorname{Re}(\mathrm{I})$ based (1 and 6). All of them, have been characterized by ${ }^{1} \mathrm{H}$ and ${ }^{13} \mathrm{C}\left\{{ }^{1} \mathrm{H}\right\}$ NMR, FT-IR, and $\mathrm{UV}$-vis spectroscopy as well as mass spectrometry, corrobo- rating the accomplishment of their synthesis. Additional ${ }^{31} \mathrm{P}\left\{{ }^{1} \mathrm{H}\right\}$ NMR was performed for complexes 2 and 7. Analysis of the $\mathrm{CO}$ stretching frequencies $(v(\mathrm{CO}))$ of all the neutral complexes showed strong CO stretching bands around 2010$1885 \mathrm{~cm}^{-1}$, which corroborate the expected carbonyl facial arrangements. $^{12}$ Alternatively, those bands for species 5-7 appear at higher frequency, around 2032 and $1917 \mathrm{~cm}^{-1}$, indicative of the less effective $\pi$-backbonding between the $\mathrm{CO}$ and $\operatorname{Re}(\mathrm{I})$ center of cationic species. Moreover, heterometallic complexes lack $v(\mathrm{H}-\mathrm{CC})$ bands, which were observed for their rhenium precursors 1 and 6 at 3222 and $3202 \mathrm{~cm}^{-1}$, respectively, indicating the success in the incorporation of the second metallic fragment. In all cases, ${ }^{1} \mathrm{H}$ NMR spectra were well-defined and showed the typical patterns for the bipyridine derivative coordinated to a $\mathrm{fac}-\mathrm{Re}(\mathrm{CO})_{3}$ core. $^{13}$ Specifically, four set of peaks were observed in the aromatic area integrating for two protons each. In addition to these aromatic protons, also those belonging to the phenyl groups in complexes $2,3,5$, and 7 appeared as multiplets. As expected, ${ }^{13} \mathrm{C}\left\{{ }^{1} \mathrm{H}\right\}$ NMR spectra also showed clearly the presence of a gold metal fragment coordinated to the alkynyl carbon as the chemical shift for those $C_{s p}$ atoms ranged from 99.5 to $110.2 \mathrm{ppm}$, whereas their $\operatorname{Re}(\mathrm{I})$ precursors 1 and 6 were at 87.3 and 79.9 ppm, respectively, see Table 1 . Additionally, ${ }^{31} \mathrm{P}\left\{{ }^{1} \mathrm{H}\right\} \mathrm{NMR}$

Table 1. Selected FTIR Stretching Bands $\left(\mathrm{cm}^{-1}\right),{ }^{13} \mathrm{C}\left\{{ }^{1} \mathbf{H}\right\}$ NMR and ${ }^{31} \mathbf{P}\left\{{ }^{1} \mathbf{H}\right\}$ NMR (ppm) Chemical Shifts of 1-7

\begin{tabular}{rlccc} 
& \multicolumn{1}{c}{$v(\mathrm{C}-\mathrm{O})$} & $v(\mathrm{H}-\mathrm{CC})$ & ${ }^{31} \mathrm{P}\left\{{ }^{1} \mathrm{H}\right\}$ & ${ }^{13} \mathrm{C}\left\{{ }^{1} \mathrm{H}\right\}\left(\mathrm{C}_{7}\right)$ \\
\hline $\mathbf{1}$ & 2016,1884 & 3222 & & 87.3 \\
$\mathbf{2}$ & 1998,1884 & & $41.5^{a}$ & $110.2^{a}$ \\
$\mathbf{3}$ & $2016,1911,1888$ & & & $101.2^{c}$ \\
$\mathbf{4}$ & 2016,1887 & & & $99.5^{d}$ \\
$\mathbf{5}$ & 2032,1917 & & & $101.7^{b}$ \\
$\mathbf{6}$ & 2034,1917 & 3220 & & $79.9^{b}$ \\
7 & 2029,1905 & & $41.0^{b}$ & $100.8^{b}$
\end{tabular}

${ }^{a 13} \mathrm{C}\left\{{ }^{1} \mathrm{H}\right\}$ NMR and ${ }^{31} \mathrm{P}\left\{{ }^{1} \mathrm{H}\right\}$ NMR were recorded in dicloromethane$\mathrm{d}_{2} .{ }^{b 13} \mathrm{C}\left\{{ }^{1} \mathrm{H}\right\}$ NMR and ${ }^{31} \mathrm{P}\left\{{ }^{1} \mathrm{H}\right\}$ NMR were recorded in acetonitrile$\mathrm{d}_{3} .{ }^{c 13} \mathrm{C}\left\{{ }^{1} \mathrm{H}\right\}$ NMR and ${ }^{31} \mathrm{P}\left\{{ }^{1} \mathrm{H}\right\}$ NMR were recorded in acetone- $\mathrm{d}_{6}$. ${ }^{d 13} \mathrm{C}\left\{{ }^{1} \mathrm{H}\right\}$ NMR and ${ }^{31} \mathrm{P}\left\{{ }^{1} \mathrm{H}\right\}$ NMR were recorded in chlorofom- $\mathrm{d}_{1}$.

spectra of complexes 2 and 7 showed a single peak at 41.5 and $41.0 \mathrm{ppm}$, respectively, corresponding to each phosphorus atom coordinated to a different gold(I) fragment. Further analytical data provided by mass spectrometry corroborated the accomplishment of the synthesis.

X-ray Diffraction. Single crystals suitable for X-ray diffraction analysis of monometallic $\operatorname{Re}(\mathrm{I})$ complexes 1 and $\mathbf{6}$ were obtained by slow diffusion of pentane and ether into a solution of DCM or chloroform, respectively. In addition to them, the heterometallic complex 3 also gave suitable crystals for X-ray diffraction by slow diffusion of hexane into an acetone solution. Relevant crystallographic data are reported in Table S1.

Complex 1 crystallized in a monoclinic crystal system with a $C 2 / c$ space group containing a $\operatorname{Re}(\mathrm{I})$ molecule together with a cocrystallized chloroform molecule within the asymmetric unit. As expected for these types of $\mathrm{d}^{6}$ metal complexes, the $\operatorname{Re}(\mathrm{I})$ coordination sphere can be described as a distorted octahedron, where the equatorial plane is formed by two carbonyl ligands and the bipyridine group. The third carbonyl together with the chloride ligand is placed in the apical axis. The source of the octahedral distortion is mainly due to the 
constriction given by the chelated ligand, whose bite angle is 75.0(1) instead of $90^{\circ}$ for an ideal octahedral geometry. The most relevant bond distances and angles are described in Figure 3, and all of them are within the range of values found

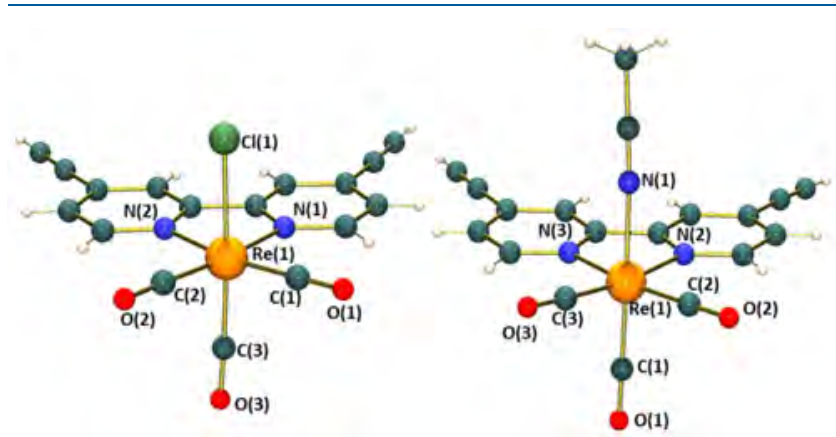

Figure 3. Povray view of one of the $\operatorname{Re}(\mathrm{I})$ molecules present in the asymmetric unit of complex 1 (left). Most relevant bond distances $(\AA)$ and angles (deg): $\operatorname{Re}(1)-C(1)$ 1.928(5), $\operatorname{Re}(1)-C(2) 1.923(6)$, $\operatorname{Re}(1)-\mathrm{C}(3)$ 1.933(4), $\operatorname{Re}(1)-\mathrm{N}(1) 2.170(4), \quad \operatorname{Re}(1)-\mathrm{N}(2)$ 2.165(4), $\operatorname{Re}(1)-\mathrm{Cl}(1) \quad 2.477(4) ; \mathrm{N}(1)-\operatorname{Re}(1)-\mathrm{N}(2) \quad 75.0(1)$, $\mathrm{N}(1)-\operatorname{Re}(1)-\mathrm{C}(1)$ 176.4(1). Povray view of one of the $\operatorname{Re}(\mathrm{I})$ molecules present in the asymmetric unit of complex 6 (right). Most relevant bond distances $(\AA)$ and angles (deg): $\operatorname{Re}(1)-C(1) 1.917(4)$, $\operatorname{Re}(1)-\mathrm{C}(2) 1.931(4), \operatorname{Re}(1)-\mathrm{C}(3)$ 1.923(4), $\operatorname{Re}(1)-\mathrm{N}(1)$ 2.132(3), $\operatorname{Re}(1)-\mathrm{N}(2)$ 2.161(3), $\operatorname{Re}(1)-\mathrm{N}(3)$ 2.179(3); N(3)$\operatorname{Re}(1)-\mathrm{N}(2) \quad 75.30(11), \mathrm{N}(1)-\operatorname{Re}(1)-\mathrm{C}(1) \quad 175.77(15)$. Triflate counterion has been removed for clarity.

for similar complexes. ${ }^{14}$ Complex 6 crystallized in a triclinic crystal system with a $P \overline{1}$ space group bearing two independent $\operatorname{Re}(\mathrm{I})$ molecules within the asymmetric unit as well as their corresponding triflate anion and a solvent pentane molecule. Once again, the $\operatorname{Re}(\mathrm{I})$ coordination sphere is described as distorted octahedron, following the same ligand distribution pattern seen for complex 1 , except for the chloride ligand which now is substituted by an acetonitrile molecule bound to the metal center through the nitrogen atom (Figure 3 right and S1). Similarly, the octahedral distortion comes from the bite angle of the $\mathrm{L}_{\mathrm{NN}}$, close in both cases to $75^{\circ}$. The angles and bond distances for both $\operatorname{Re}(\mathrm{I})$ molecules within the asymmetric unit are very similar, being in both cases the longer $\mathrm{Re}-\mathrm{N}$ and $\mathrm{Re}-\mathrm{C}$ bond distances, these of the nitrogen belonged to the acetonitrile and carbon from the axial carbonyl ligand, respectively. The most relevant bond distances and angles are described in Figure 3 (right structure) and Figure S1.

Alternatively, the heterotrimetallic species 3 crystallized in an orthorhombic crystal system and in a Pnma space group together with a molecule of acetone from the crystallization solvent mixture. The asymmetric unit is formed by half of a molecule, denoting the symmetry of the structure. As in previous examples, the rhenium metal center is disposed in an octahedral environment with a $\mathrm{N}-\mathrm{Re}-\mathrm{N}$ angle of $75.1(3)^{\circ}$. As expected, the gold atoms are coordinated in a linear fashion to the terminal alkynyl carbon and the carbene carbon with a $\mathrm{C}(1)-\mathrm{Au}(1)-\mathrm{C}(10)$ angle of $173.8(4)$. Relevant bond distances and angles can be seen in Figure 4. The chlorine and a carbonyl ligands coordinated to rhenium atom in trans positions have been found to be disordered. They have been included in the model in two sets of positions, but only one is shown in the drawing and in the distances and angles below.

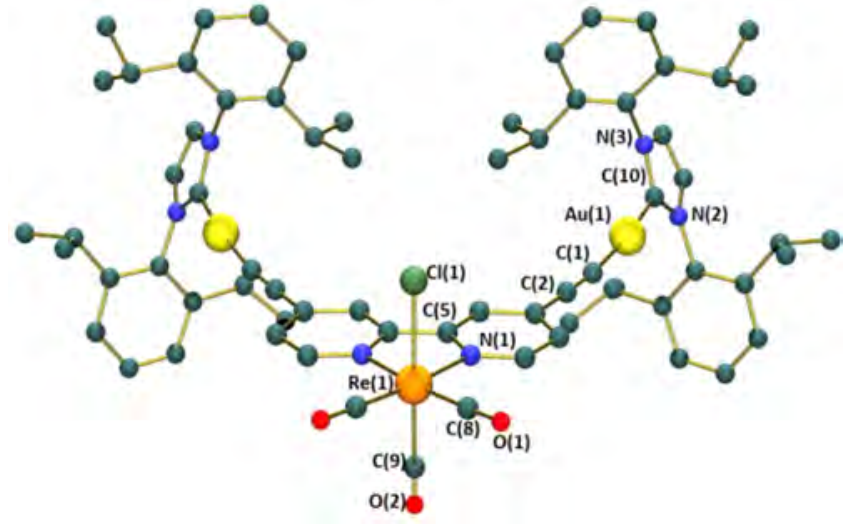

Figure 4. Povray view of complex 3. Most relevant bond distances (A) and angles (deg): $\operatorname{Re}(1)-C(8)$ 1.912(9), $\operatorname{Re}(1)-C(9) 1.99(5)$, $\mathrm{Re}(1)-\mathrm{Cl}(1)$ 2.408(7), $\operatorname{Re}(1)-\mathrm{N}(1)$ 2.165(6); N(1)-Re(1)-N(1) 75.2(4), N(1)-Re(1)-C(8) 99.2(4), N(1)-Re(1)-C(9) 87.9(3), $\mathrm{Cl}(1)-\mathrm{Re}(1)-\mathrm{C}(9)$ 176.1(7); C(1)-Au(1) 1.998(9), C(10)-Au(1) 2.024(9); C(1)-Au(1)-C(10) 173.8(4).

Photophysical Studies. UV-vis absorption spectra were recorded for complexes $1-7$ in a dimethyl sulfoxide solution at 298 K, see Table 2 and Figure S2. All of them showed a similar

Table 2. Absorption, Emission, Excitation Maxima of 1-7 in DMSO Solution at $298 \mathrm{~K}$

\begin{tabular}{|c|c|c|c|}
\hline complex & $\lambda_{\mathrm{abs}} / \mathrm{nm}\left(10^{4} \varepsilon / \mathrm{dm}^{3} \times \mathrm{mol}^{-1} \times \mathrm{cm}^{-1}\right)$ & $\lambda_{\mathrm{em}} / \mathrm{nm}\left(\lambda_{\mathrm{em}} /\right.$ & $\tau / \mathrm{ns}$ \\
\hline 1 & $\begin{array}{l}261(2.03), 308(1.33), 333(0.88) \\
\quad 398(0.40)\end{array}$ & $680(468)$ & 12 \\
\hline 2 & $\begin{array}{l}276(4.23), 304(4.25), 340(2.39) \\
\quad 395(1.26)\end{array}$ & $651(473)$ & 80 \\
\hline 3 & $\begin{array}{l}272(3.65), 310(4.34), 343(2.44) \\
\quad 385(1.07)\end{array}$ & $635(451)$ & \\
\hline 4 & $\begin{array}{l}273(3.66), 304(4.99), 340(2.33) \\
390(1.11)\end{array}$ & $663(477)$ & 44 \\
\hline 5 & $\begin{array}{l}272(1.59), 289(1.78), 306(1.18) \\
\quad 345(1.88)\end{array}$ & $565(401)$ & \\
\hline 6 & $\begin{array}{l}262(2.93), 323(1.42), 338(1.51) \\
\quad 356(0.67)\end{array}$ & $619(437)$ & 123 \\
\hline 7 & $\begin{array}{l}270(3.31), 301(3.33), 344(2.17) \\
\quad 373(1.15)\end{array}$ & $585(421)$ & 302 \\
\hline
\end{tabular}

absorption profile that can be defined as a combination of ligand centered transitions $\left({ }^{1} \mathrm{LC}\right)$ at higher energies and a metal-to-ligand charge transfer transition $\left({ }^{1} \mathrm{MLCT}\right)$ at lower energies. Specifically, the absorption bands observed at approximately $270 \mathrm{~nm}$ and between 300 and $350 \mathrm{~nm}$ can be assigned to $\pi \rightarrow \pi^{*}$ (bipy, $\left.\mathrm{Ph}\right)$ and $\pi \rightarrow \pi^{*}(\mathrm{C} \equiv \mathrm{C})$ transitions, in concordance with similar alkynylbisimine $\operatorname{Re}(\mathrm{I})$ derivatives described in the literature. ${ }^{15}$ Additionally, the broad band close to $400 \mathrm{~nm}$, with a tail up to $450 \mathrm{~nm}$ in some cases, is attributed to $\operatorname{Re}(\mathrm{d} \pi) \rightarrow \mathrm{L}\left(\pi^{*}\right)$ transitions. The extended tail of this ${ }^{1}$ MLCT band is probably due to the extended electronic delocalization among the alkynylbipyridine derivatives. In addition to the absorption measurements, emission measurements for all the species were analyzed in dimethyl sulfoxide at $298 \mathrm{~K}$, Figure 5, and the most relevant data are collected in Table 2. Their emission patterns are alike, a broad emission band with the maxima between 565 and $680 \mathrm{~nm}$, and the lifetime value ranges from 12 to 302 ns. As expected, cationic species have their maxima blue-shifted in comparison with their neutral counterparts ${ }^{16}$ due to the less electron density on 


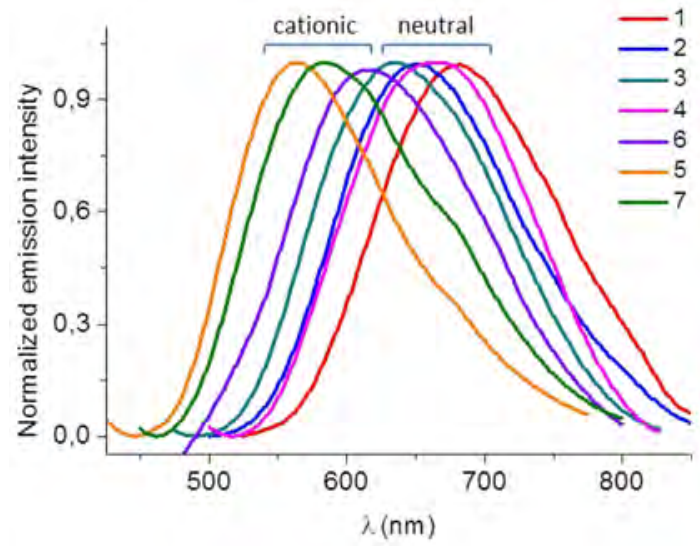

Figure 5. Normalized emission spectra for complexes 1-7 in dimethyl sulfoxide at $298 \mathrm{~K}$.

the metal center that ultimately stabilizes the HOMO orbitals. In all cases the emission can be assigned to a ${ }^{3} \mathrm{MLCT}$ transition from the $\mathrm{d} \pi(\mathrm{Re}) \rightarrow \pi^{*}$ (diimine), which has been previously reported in many rhenium(I) diimine tricarbonyl analogues. ${ }^{6}$ It is worth noticing that the heterotrimetallic analogues, both the neutral 2-4 and the cationic 5 and 7, presented their maxima at higher energies than their monometallic $\operatorname{Re}(\mathrm{I})$ precursors, complexes $\mathbf{1}$ and $\mathbf{6}$, respectively. Such behavior has been already seen for similar $\operatorname{Re}(\mathrm{I}) / \mathrm{Au}(\mathrm{I})$ species, ${ }^{15,17}$ and it can be explained based on the additional electron density that the gold fragment renders to the diimine. Higher electron donation into the diimine promotes the destabilization of the LUMO orbital, which is mainly centered in this ligand. Thus, the gold ancillary ligand nature and its ability to donate or withdraw electron density can be used to fine-tune the emission of the complexes, see Table $2 .{ }^{18}$ On the basis of these data, if there was a breakage or decoordination of the gold fragment or even substitution of the gold ancillary ligand when the interaction with the biological target takes place, fluorescence spectroscopy would allow detection of the precise moment of such an interaction, which was one of the requirements for the devised probes.

Antiproliferative Studies. The antipoliferative activity of complexes 1 to 7 was analyzed by MTT assay in the human lung cancer and breast cancer cell lines, A549 and HeLa, see Table 3. The experiments were performed at different incubation times, 24 and $72 \mathrm{~h}$, as it is known that alkynyl gold derivatives need longer times to reveal their cytotoxicity in comparison to auranofin analogues (-SAuP-) or bisphosphines (PAuP) derivatives. ${ }^{19}$ The fact that the goldcarbon bond in alkynyl gold complexes is one of the strongest gold-ligand bonds ${ }^{20}$ might be the driving force for delayed

Table 3. $\mathrm{IC}_{50}$ values $(\mu \mathrm{M})$ of Complexes 1-7 Measured by MTT in A549 and HeLa Cells after 24 and $72 \mathrm{~h}$ Incubation

\begin{tabular}{lllll} 
& A549-24 h & \multicolumn{1}{c}{ A549-72 h } & HeLa-24 h & HeLa-72 h \\
$\mathbf{1}$ & $>25$ & $18.51 \pm 3.71$ & $17.01 \pm 1.84$ & $7.15 \pm 0.47$ \\
$\mathbf{2}$ & $>50$ & $>25$ & $>25$ & $6.46 \pm 0.35$ \\
$\mathbf{3}$ & $>50$ & $>25$ & $>25$ & $>25$ \\
$\mathbf{4}$ & $>50$ & $>25$ & $>25$ & $10.79 \pm 0.48$ \\
$\mathbf{5}$ & $>25$ & $>25$ & $>25$ & $16.4 \pm 2.80$ \\
$\mathbf{6}$ & $8.37 \pm 0.29$ & $4.92 \pm 0.38$ & $5.10 \pm 0.45$ & $1.16 \pm 0.13$ \\
7 & $>25$ & $17.52 \pm 1.40$ & $18.8 \pm 1.15$ & $2.35 \pm 0.06$
\end{tabular}

time action. There is a clear difference between the antiproliferative activity of monometallic and heterometallic complexes, presenting the later higher cell selectivity toward HeLa cells at longer times. Moreover, greater cytotoxicity was seen for the cationic over neutral species. Specifically, the heterotrimetallic neutral complexes 2 and $\mathbf{4}$ showed selective antiproliferative activity after $72 \mathrm{~h}$ in the HeLa cell line, with $\mathrm{IC}_{50}$ values of 6.46 and $10.79 \mu \mathrm{M}$, respectively, whereas in the case of complex 3 the $\mathrm{IC}_{50}$ value was over $25 \mu \mathrm{M}$. On the contrary, the neutral $\operatorname{Re}(\mathrm{I})$ precursor, complex 1 , already showed antiproliferative activity in A549 at $72 \mathrm{~h}$ as well as in HeLa cells at $24 \mathrm{~h}$. The same trend has been shown by the cationic $\operatorname{Re}(\mathrm{I})$ complex 6 , in this case with excellent $\mathrm{IC}_{50}$ values $(<8 \mu \mathrm{M})$ probably because of its higher solubility. Regarding the cationic heterotrimetallic species, complexes 5 and 7, the selectivity toward inhibiting the proliferation of HeLa cells was not as evident as for their neutral analogue complexes 2-4, since complex 7 already showed a moderate cytotoxicity in A549 at $72 \mathrm{~h}$ and HeLa cells at $24 \mathrm{~h}$ (ca. $18 \mu \mathrm{M}$ ). However, it is clear that the mechanism of action of the heterotrimetallic probes involves somehow the gold fragment, which is what ultimately is providing the cell selectivity at longer times. Otherwise, the $\mathrm{IC}_{50}$ values of heterometallic complexes would be similar to those of their parent monometallic $\operatorname{Re}(\mathrm{I})$ complexes, where time dependence and cell selectivity were not clearly displayed. A closer look at the $\mathrm{IC}_{50}$ values also suggests that the gold ancillary ligands influence the cytotoxic behavior following the trend $-\mathrm{PPh}_{3}>-\mathrm{CN}^{\mathrm{t} B u}>-\mathrm{IPr}$, where the phosphine derivative is the most cytotoxic. Their role in the mechanism of action, or the way that they interfere within the internalization process of the probe might explain such behavior. Gold ancillary ligands are able to modulate the cellular uptake considerably due to their different lipo- or hydrophilic character, which is crucial for delivering the cytotoxic agent. $^{21}$

In addition, the intracellular amount of $\mathrm{Au}(\mathrm{I})$ was analyzed by ICP-mass spectrometry for analogous neutral and cationic heterometallic complexes, species 2 and 7 , respectively, in HeLa cells. The analyses showed that the cellular uptake of gold was double for 7 than that for 2 , revealing the importance of the cationic nature for the internalization of the complexes, see Table 4. Moreover, it is worth mentioning that $\mathrm{IC}_{50}$ values

Table 4. Quantity of Gold ( $\mu \mathrm{M})$ Measured Inside HeLa Cells by ICP Mass Spectrometry after Incubation for $4 \mathrm{~h}$

$\begin{array}{cc}\text { complex } & \mu \mathrm{g} \text { gold } / 10^{5} \text { cells } \\ 2 & 1.420 \pm 0.014 \\ 7 & 2.207 \pm 0.017\end{array}$

are a combination of the intrinsic toxicity of the samples and their ability of internalization and solubility in biological media. $^{22}$ Therefore, it seems clear that in this case, the ratio of toxicity for cationic to neutral complexes is higher than the ratio of uptake, corroborating that the intrinsic cytotoxicity of cationic species is greater than that of their neutral counterparts.

Fluorescence Microscopy. Cell distribution of complexes 1-7 was studied by fluorescence microscopy in A549 cells. In addition to them, either LysoTracker or MitoTracker were used as an internal standard to ascertain the localization pattern of the metallic species. Specifically, cell images were recorder after incubating $1-7$ at $25 \mu \mathrm{M}$ for $24 \mathrm{~h}$ in order to 
not greatly increase the $\mathrm{IC}_{50}$ concentration. The irradiation wavelength used was thoroughly selected depending on their specific excitation and emissive properties, i.e., $\lambda_{\text {exc }}=474 \mathrm{~nm}$, and collecting the emission between 490 and $590 \mathrm{~nm}$ for neutral and $\lambda_{\text {exc }}=405 \mathrm{~nm}$ and the emission window between 550 and $650 \mathrm{~nm}$ for cationic species.

In general, precipitation of the complexes was observed in the extracellular region, which prevailed over accumulation inside the cell, particularly evident for those complexes of a neutral nature, 1-4, incubated at a high concentration in A549. Figure 6 showed an example of the extracellular precipitate of complexes 1 and 2 .
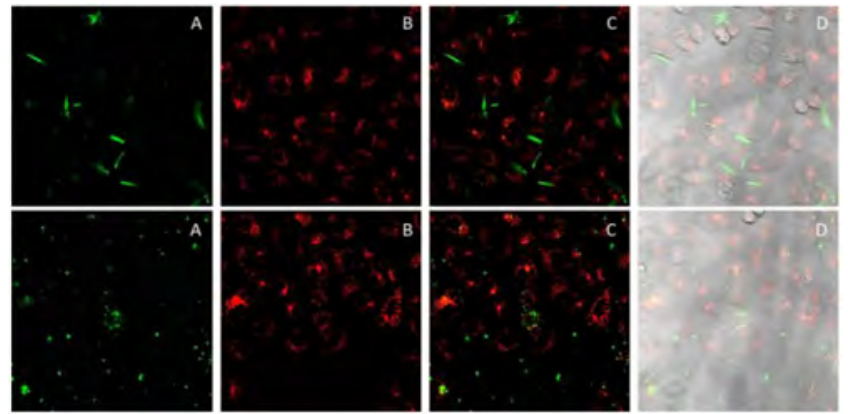

Figure 6. Images of $\mathbf{1}$ (top row) and $\mathbf{2}$ (botton row) after incubation with A549 (24 h) and LysoTracker Red-DND99 (30 min). (A) Image after irradiation at 473; (B) after irradiation at $588 \mathrm{~nm}$; (C) superimposition picture of $A$ and $B$; (D) superimposition with bright field image. Green, complexes 1 and 2; red, internal standard.

Moreover, a comparison between the images recorded for complexes 1 and $\mathbf{2}$ (Figure 6) and for complexes 3 and 4 (Figure S3), the four of them incubated with A549 cells under the same conditions, clearly showed the lower solubility properties of species 3 and 4 . Therefore, it can be suggested that the gold ancilliary ligands of complexes 3 and 4, i.e., IPr and $\mathrm{CN}^{\mathrm{t}} \mathrm{Bu}$, greatly contributed to the low solubility of the compounds. The cationic species 5 and 7 followed a similar trend as their neutral counterparts when incubated with A549 cells, and only the precipitated complex was clearly seen in the surroundings of the cells, see Figure S4. Alternatively, the monometallic rhenium complex 6 incubated in A549 at $25 \mu \mathrm{M}$ led directly to cell death, see Figure 7 , corroborating the low $\mathrm{IC}_{50}$ value of $8.37 \pm 0.29 \mu \mathrm{M}$ found for this particular species.

In addition to the analysis of the distribution of complexes 1-7 in A549 cells, further fluorescence microscopy studies were performed in HeLa cells to evaluate the higher antiproliferative activity displayed in this cell line. Thus, complexes 1-7 were incubated with HeLa cells for $24 \mathrm{~h}$, this time at $5 \mu \mathrm{M}$ in order to prevent a high percentage of cell death. Analogous to the previous image assay, a considerable amount of precipitate was observed in the outer cell membrane media for the heterotrimetallic species. The main difference with the previous experiment (see Figure 6 and S3) is that most of the precipitate is located very close to the cell membrane, see Figures 8 and S5. Therefore, it seems plausible to think that an interaction with the membrane of HeLa cells could be taking place. Despite that, none of the species could be seen inside the cell, and elucidation of their inner distribution or interaction could not be made. The fact that no heterotrimetallic complex was seen inside the cell could be

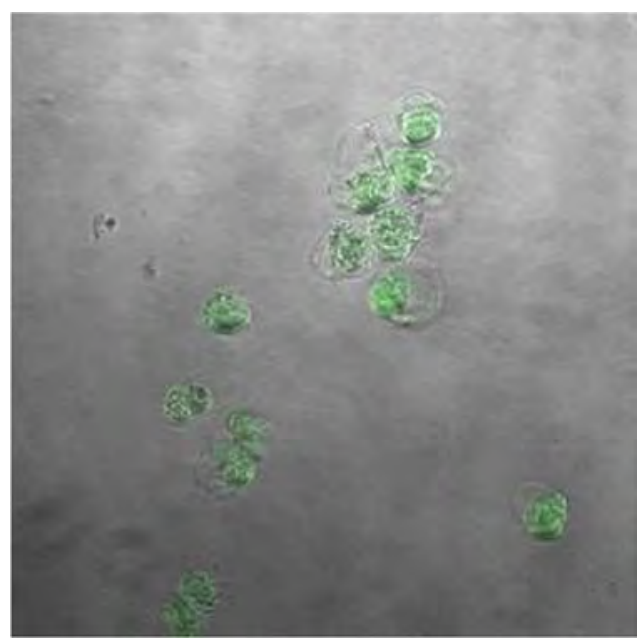

Figure 7. Complex 6 incubated with A549 at $25 \mu \mathrm{M}$ for $24 \mathrm{~h}$.
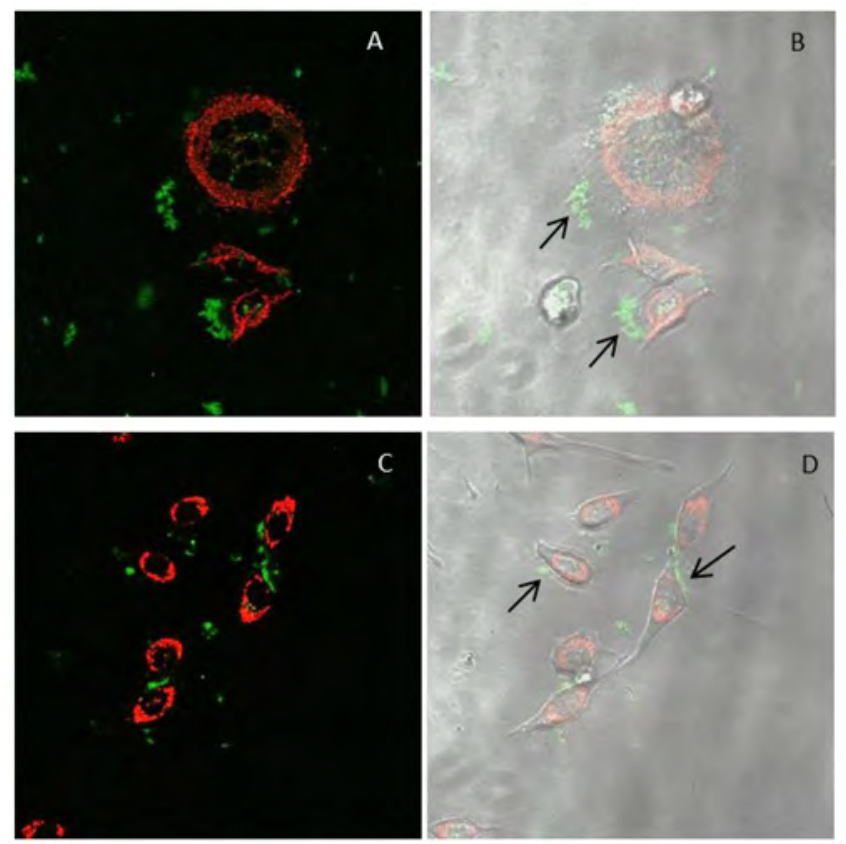

Figure 8. Images of $\mathbf{2}$ (top row) and $\mathbf{4}$ (botton row) after incubation with HeLa $(24 \mathrm{~h})$ at $5 \mu \mathrm{M}$ and MitoTracker Red (15 min). Red emission: MitoTracker. Green emission of complexes 2 and 4. (A) Emission of the complex 2 and MitoTracker; (B) superimposition with bright field. (C) Emission of the complex 4 and MitoTracker; (D) superimposition with bright field image.

due to either poor cell permeability, low emission efficiency, or even emission quenching processes.

In a final attempt to shed a bit of light on the different antiproliferative characters of the heterotrimetallic complexes in HeLa cells in comparison with A549, a different experiment was performed. This time the complexes were incubated with HeLa cells at $25 \mu \mathrm{M}$ while reducing the incubation time to $4 \mathrm{~h}$ in order not to disrupt the cell viability. The experiment was only performed for the cationic species $(5-7)$ due to the low solubility displayed for the neutral species in the previous assays as well as their lower internalization found by ICP-mass spectrometry. Thus, monometallic $\operatorname{Re}(\mathrm{I})$ complex 6 revealed the cell immersed in a cell death process, which corroborates the high cytotoxicity observed for this complex in HeLa cells at 
only $24 \mathrm{~h}$ of incubation $(5.10 \pm 0.45 \mu \mathrm{M})$, see Figure 9. No solid was observed outside the cell, suggesting that the complex has been internalized.

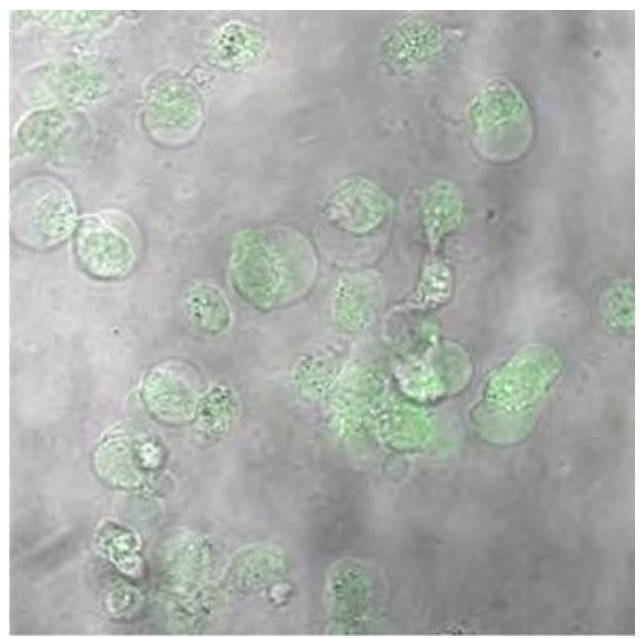

Figure 9. Images of 6 after incubation with HeLa $(4 \mathrm{~h})$ at $25 \mu \mathrm{M}$.

Following the same trend as before, when incubated at 5 $\mu \mathrm{M}$, cationic species $\mathbf{5}$ and 7 got stuck and/or adhered to the outer part of the cell membrane, see Figure 10. Such a
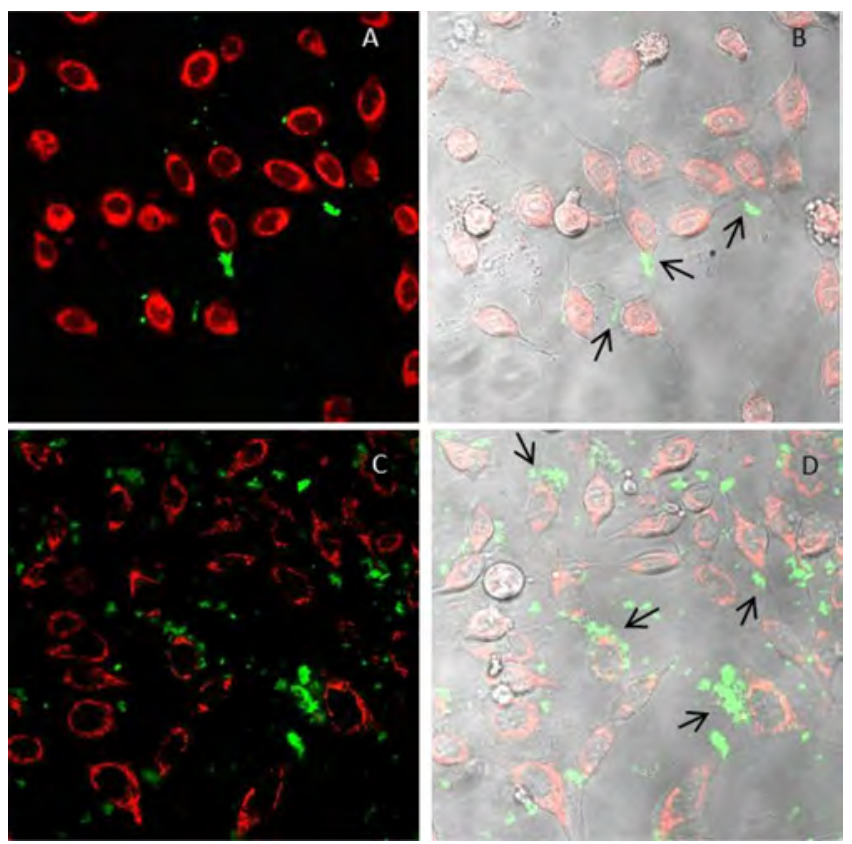

Figure 10. Images of 5 (top row) and 7 (botton row) after incubation with HeLa $(4 \mathrm{~h})$ at $25 \mu \mathrm{M}$ and MitoTracker Red (15 min). Red emission: MitoTracker. Green emission of complexes 5 and 7. (A) Emission of the complex $\mathbf{5}$ and MitoTracker; (B) superimposition with bright field. (C) Emission of the complex 7 and MitoTracker; (D) superimposition with bright field image at $25 \mu \mathrm{M}$ for $4 \mathrm{~h}$.

localization pattern on HeLa cells, completely different from that seen in A549 cells, where the solid was randomly distributed through the outer cell media (Figure S4), might be the key for the higher selectivity and cytotoxicity seen toward the HeLa cell line. In addition, it is worth noticing that the presence of the gold fragment is somehow implicated in such a localization pattern, since the monometallic $\operatorname{Re}(\mathrm{I})$ species complex 6 behaves completely differently and no solid is distributed within the surroundings of the cell, Figure 9 vs Figure 10. Therefore, it can be concluded that the mechanisms of action of monometallic rhenium and trimetallic rhenium/ gold derivatives differ from each other. Moreover, it is feasible to think that the gold fragment is the driving force toward the cell selective cytotoxicity and that differences in the membrane composition of HeLa and A549 cells might be encouraging such differentiation. In fact, cancer cells present lipid alterations in their cell membrane. ${ }^{23}$ Studies have shown variations of phospholipid-to-protein, cholesterol-to-protein, and cholesterol-to-phospholipid ratios, as well as in the fatty acid composition of the phospholipids of different cancer cell line membranes, ${ }^{24}$ which in this case must be critical for the cell specificity of our heterometallic probes.

\section{EXPERIMENTAL SECTION}

General Measurements and Analysis Instrumentation. Mass spectra were recorded on a Bruker Esquire 3000 Plus, with the electrospray (ESI) technique, and on a Bruker MALDI-TOF device. ${ }^{1} \mathrm{H},{ }^{13} \mathrm{C}\left\{{ }^{1} \mathrm{H}\right\}$, and ${ }^{31} \mathrm{P}\left\{{ }^{1} \mathrm{H}\right\} \mathrm{NMR}$, including $2 \mathrm{D}$ experiments, were recorded at room temperature on a Bruker Avance 400 spectrometer $\left({ }^{1} \mathrm{H}, 400 \mathrm{MHz},{ }^{13} \mathrm{C}, 100.6 \mathrm{MHz},{ }^{31} \mathrm{P}, 162 \mathrm{MHz}\right)$ with chemical shifts $(\delta, \mathrm{ppm})$ reported relative to the solvent peaks of the deuterated solvent. Infrared spectra were recorded in the range $4000-250 \mathrm{~cm}^{-1}$ on a PerkinElmer Spectrum 100 FTIR spectrometer. Room temperature steady-state emission and excitation spectra were recorded with a Jobin-Yvon-Horiba fluorolog FL3-11 spectrometer fitted with a JY TBX picosecond detection module. Nanosecond lifetimes were recorded with a Datastation HUB-B with a nanoLED controller and DAS6 software. The nanoLEDs employed for lifetime measurements were of 370 and $390 \mathrm{~nm}$. The lifetime data were fitted using the Jobin-Yvon software package and the Origin Pro 8 program. $\mathrm{UV}$-vis spectra were recorded with $1 \mathrm{~cm}$ quartz cells on an Evolution 600 spectrophotometer. The quantum yields were measured in a 300-950 nm Hamamatsu Photonics Quantaurus-QY.

Crystal Structure Determinations. Crystals were mounted in inert oil on glass fibers and transferred to the cold gas stream of an Xcalibur Oxford Diffraction diffractometer or Bruker Apex Duo equipped with low-temperature attachments. Data were collected using monochromated Mo $\mathrm{K} \alpha$ radiation $(\lambda=0.71073 \AA)$. The scan type was $\omega$. Absorption correction based on multiple scans was applied using spherical harmonics implemented in the SCALE3 ABSPACK scaling algorithm ${ }^{25}$ or with SADABS. The structures were solved by direct methods and refined on $F^{2}$ using the program SHELXL-2016. ${ }^{26}$

Antiproliferative Studies: MTT Assay. Exponentially growing cells (A549 or HeLa) were seeded at a density of approximately $10^{4}$ cells per well in 96-well flat-bottomed microplates and allowed to attach for $24 \mathrm{~h}$ prior to the addition of compounds. The complexes were dissolved in DMSO and added to cells in concentrations ranging from 50 to $0.5 \mu \mathrm{M}$ or by 25 to $0.50 .5 \mu \mathrm{M}$, in quadruplicate. Cells were incubated with our compounds for 24 or $72 \mathrm{~h}$ at $37{ }^{\circ} \mathrm{C}$. Ten microliters of MTT ( $5 \mathrm{mg} \mathrm{mL}^{-1}$ ) was added to each well, and plates were incubated for $2 \mathrm{~h}$ at $37^{\circ} \mathrm{C}$. Finally, the growth medium was eliminated, and DMSO (100 $\mu \mathrm{L}$ per well) was added to dissolve the formazan precipitates. The optical density was measured at $550 \mathrm{~nm}$ using a 96-well multiscanner autoreader (ELISA). The $\mathrm{IC}_{50}$ was calculated by nonlinear regression analysis.

ICP-Mass. Twelve-well plates were seeded with $10^{5}$ cells (Hela/ A549) in $1.6 \mathrm{~mL}$ of culture medium per well. Cultures were incubated at $37{ }^{\circ} \mathrm{C}$ in an atmosphere of $5 \% \mathrm{CO}_{2} / 95 \%$ for $24 \mathrm{~h}$. The culture medium was then removed and replaced with $2 \mathrm{~mL}$ of drug containing medium at $25 \mu \mathrm{M}$. After $4 \mathrm{~h}$ of incubation at $37^{\circ} \mathrm{C}$, the medium was removed and the cell monolayer washed two times with phosphate-buffer saline. Then, $1 \mathrm{~mL}$ of a trypsine solution was added, and the plate was placed in the incubator for $5 \mathrm{~min}$. A total of $500 \mu \mathrm{L}$ 
of fresh medium was then added, and the resulting suspension was pelleted in a $1.5 \mathrm{~mL}$ eppendorf by centrifuging for $5 \mathrm{~min}$ at $1200 \mathrm{rpm}$. The pellets were resuspended in $500 \mu \mathrm{L}$ of fresh medium, and a $50 \mu \mathrm{L}$ fraction was separated for cell counting after staining with Trypan Blue. The suspension was centrifuged again. The medium was removed, and $0.5 \mathrm{~mL}$ of concentrated aqua regia was added for digestion overnight. The resulting solutions were diluted gravimetrically with ultrapure water and analyzed by ICP-MS. Measurements were performed by an ICP quadrupole mass spectrometer (Elan DRC-e, PerkinElmer, Shelton, CT, USA) equipped with a standard ICP torch, cross-flow nebulizer, nickel sampler, and skimmer cones and DRC. PTFE vessels, micropipette tips, eppendorfs for digestion, and polypropylene (PP) tubes were cleaned in $10 \% \mathrm{HNO}_{3}$ overnight and rinsed thoroughly with ultrapure water.

Cell Fluorescence Microscopy Study. The European Collection of Cell Cultures was maintained in HEPES modified minimum essential medium (DMEM) supplemented with 5\% fetal bovine serum, penicillin, and streptomycin. A549 cells were detached from the plastic flask using trypsin-EDTA solution and suspended in an excess volume of growth medium. A total of $300 \mu \mathrm{L}$ of a homogeneous cell suspension was then distributed into an $\mu$-slide 8 well ibiTreat; the cells were allowed to attach for $24 \mathrm{~h}$ prior to the addition of compounds. Then, $200 \mu \mathrm{L}$ of culture medium was removed, and $100 \mu \mathrm{L}$ of a solution of the corresponding complexes was added to the cells up to a final concentration of 5 or $25 \mu \mathrm{M}$. The complexes were incubated with the cells for 4 or $24 \mathrm{~h}$ at $37{ }^{\circ} \mathrm{C}$, depending on the experiment. Thereafter, $50 \mu \mathrm{L}$ of MitoTracker Red or LysoTracker Red DND-99 was added up to a final concentration of $10 \mathrm{nM}$. They were incubated with the cells for $15 \mathrm{~min}$ (MitoTracker) or $30 \mathrm{~min}$ (LysoTracker) at room temperature. Eventually, the medium was replaced with fresh medium without phenol red. Preparations were viewed using an Olympus FV10-i Oil type compact confocal laser microscope using a $\times 10$ or $\times 60$ objective, with excitation wavelengths at 405,473 , and $588 \mathrm{~nm}$.

Materials and Procedures. The starting material $[\mathrm{Au}(\mathrm{acac})-$ $\left.\left(\mathrm{PPh}_{3}\right)\right],{ }^{27}\left[\mathrm{Au}\left(\mathrm{CN}^{\mathrm{t} B u}\right) \mathrm{Cl}\right],{ }^{28}\left[\mathrm{AuCl}\left(\mathrm{PPh}_{3}\right)\right],{ }^{29}$ and $[\mathrm{AuClIPr}]^{30}$ were prepared according to literature procedures, and their experimental data agree with those reported. ${ }^{27-30}$ All other starting materials and solvents were purchased from commercial suppliers and used as received unless otherwise stated.

Synthesis of Complex 1. 4,4'-Alkynyl-2,2'-bipyridine ( $\mathrm{L}_{\mathrm{NN}} ; 129$ $\mathrm{mg}, 0.632 \mathrm{mmol})$ and $\left[\operatorname{Re}(\mathrm{CO})_{5} \mathrm{Cl}\right](228.7 \mathrm{mg}, 0.632 \mathrm{mmol})$ were suspended in toluene $(10 \mathrm{~mL})$ and heated at $80{ }^{\circ} \mathrm{C}$ for $8 \mathrm{~h}$. The suspension was cooled to room temperature, and the solid was filtered and then washed with a small amount of toluene and petroleum ether. The compound was obtained as an orange solid (306.3 mg, 95\%). ${ }^{1} \mathrm{H}$ NMR (400 MHz, $\left.\mathrm{CDCl}_{3}\right): \delta 9.01\left(\mathrm{~d}, J=5.8 \mathrm{~Hz}, 2 \mathrm{H}, \mathrm{H}_{6}\right), 8.20$ (sbr, $\left.2 \mathrm{H}, \mathrm{H}_{3}\right), 7.55\left(\mathrm{dd}, J=5.8,1.7 \mathrm{~Hz}, 2 \mathrm{H}, \mathrm{H}_{5}\right), 3.65$ (s, $\left.2 \mathrm{H}, \mathrm{H} 8\right) .{ }^{13} \mathrm{C}$ NMR (101 MHz, CDCl3): $\delta 196.9$ (s, CO), 190.3 (s, CO), 155.3 (s, 2C, $\mathrm{C}_{6}$ ), $153.2\left(\mathrm{~s}, 2 \mathrm{C}, \mathrm{C}_{2}\right), 133.9$ (s, 2C, $\left.\mathrm{C}_{4}\right), 129.6$ (s, 2C, $\left.\mathrm{C}_{3}\right), 128.3$ $\left(\mathrm{s}, 2 \mathrm{C}, \mathrm{C}_{8}\right), 125.7\left(\mathrm{~s}, 2 \mathrm{C}, \mathrm{C}_{5}\right), 87.3\left(\mathrm{~s}, 2 \mathrm{C}, \mathrm{C}_{7}\right)$. IR (v, cm-1): 3222 $(\mathrm{C} \equiv \mathrm{C}-\mathrm{H}), 3056(\mathrm{CAr}-\mathrm{H}), 2107$ (C三C), 2016, 1884 (CO), 1605 $(\mathrm{CAr}=\mathrm{N})$. HRMS $(\mathrm{m} / z): 532.9685[\mathrm{M}-\mathrm{Cl}+\mathrm{Na}]$, $\mathrm{C}_{17} \mathrm{H}_{8} \mathrm{ClN}_{2} \mathrm{NaClO}_{3} \mathrm{Re}(532.9664)$.

Synthesis of Complex 2. To a stirred solution of complex 1 (13 $\mathrm{mg}, 0.0255 \mathrm{mmol})$ in DCM $(2.5 \mathrm{~mL})$ was added $\left[\mathrm{Au}(\mathrm{acac})\left(\mathrm{PPh}_{3}\right)\right]$ $(28.2 \mathrm{mg}, 0.051 \mathrm{mmol})$. After $3 \mathrm{~h}$ of stirring at room temperature, the solvent was reduced to minimum volume, and petroleum ether was added to afford a yellow solid (yield $28.6 \mathrm{mg}, 79 \%) .{ }^{1} \mathrm{H}$ NMR (300 $\left.\mathrm{MHz}, \mathrm{CD}_{2} \mathrm{Cl}_{2}\right): \delta 8.78\left(\mathrm{~d}, J=5.8 \mathrm{~Hz}, 2 \mathrm{H}, \mathrm{H}_{6}\right), 8.10(\mathrm{~d}, J=1.7 \mathrm{~Hz}$, $\left.2 \mathrm{H}, \mathrm{H}_{3}\right), 7.63-7.45\left(\mathrm{~m}, 30 \mathrm{H}, \mathrm{H}_{\mathrm{Ar}} \mathrm{Ph}\right), 7.41(\mathrm{dd}, J=5.8,1.6 \mathrm{~Hz}, 2 \mathrm{H}$, $\left.\mathrm{H}_{5}\right) .{ }^{13} \mathrm{C} \mathrm{NMR}\left(75 \mathrm{MHz}, \mathrm{CD}_{2} \mathrm{Cl}_{2}\right): \delta 198.47$ (s, CO), 155.85 (s, 2C, $\left.\mathrm{C}_{2}\right), 152.76\left(\mathrm{~s}, 2 \mathrm{C}, \mathrm{C}_{6}\right), 137.62\left(\mathrm{~s}, 2 \mathrm{C}, \mathrm{C}_{4}\right), 134.86\left(\mathrm{~d},{ }^{2} \mathrm{~J}_{\mathrm{P}-\mathrm{C}}=13.8\right.$ $\mathrm{Hz}, 12 \mathrm{C}, o-\mathrm{C}, \mathrm{Ph}), 132.38(\mathrm{~s}, 12 \mathrm{C}, p-\mathrm{C}, \mathrm{Ph}), 129.99\left(\mathrm{~d},{ }^{1}{ }_{\mathrm{P}-\mathrm{C}}=57.3\right.$ $\mathrm{Hz}, 6 \mathrm{C}, i-\mathrm{C}, \mathrm{Ph}), 129.86\left(\mathrm{~d},{ }^{2} J_{\mathrm{P}-\mathrm{C}}=11.3 \mathrm{~Hz}, 12 \mathrm{C}, m-\mathrm{C}, \mathrm{Ph}\right), 129.86$ $\left(\mathrm{s}, 2 \mathrm{C}, \mathrm{C}_{5}\right), 126.37$ (s, 2C, $\left.\mathrm{C}_{3}\right), 110.60$ (s, 1C, $\left.\mathrm{C}_{8}\right), 100.22\left(\mathrm{~s}, 1 \mathrm{C}, \mathrm{C}_{7}\right)$. ${ }^{31} \mathrm{P}$ NMR (121 MHz, $\left.\mathrm{CD}_{2} \mathrm{Cl}_{2}\right): \delta 41.5(\mathrm{~s})$. IR $\left(v, \mathrm{~cm}^{-1}\right): 3046\left(\mathrm{C}_{\mathrm{Ar}}-\right.$ $\mathrm{H}), 2107(\mathrm{C} \equiv \mathrm{C}), 1998,1884(\mathrm{CO}), 1600\left(\mathrm{C}_{\mathrm{Ar}}=\mathrm{N}\right)$. MALDIHRMS $(m / z): 1391.1089 \quad[\mathrm{M}-\mathrm{Cl}], \mathrm{C}_{53} \mathrm{H}_{36} \mathrm{Au}_{2} \mathrm{~N}_{2} \mathrm{O}_{3} \mathrm{P}_{2} \mathrm{Re}$ (1391.1090).
Synthesis of Complex 3. To a stirred solution of complex 1 (15 $\mathrm{mg}, 0.0294 \mathrm{mmol})$ and [AuClIPr] $(36.6 \mathrm{mg}, 0.589 \mathrm{mmol})$ in $\mathrm{MeOH}$ $(5 \mathrm{~mL})$ was added a solution of $\mathrm{KOH}(3.87 \mathrm{mg}, 0.0588 \mathrm{mmol})$ in $\mathrm{MeOH}(3 \mathrm{~mL})$. The mixture was stirred $24 \mathrm{~h}$ at room temperature and then purified by alumina column chromatography employing ether/MeOH (97:3 to 93:7). The product was obtained as a yellow solid (yield $22.4 \mathrm{mg}, 45 \%)$. ${ }^{1} \mathrm{H}$ NMR (300 MHz, acetone- $\mathrm{d}_{6}$ ): $\delta 8.67$ $\left(\mathrm{d}_{\mathrm{br}}, J=5.8 \mathrm{~Hz}, 2 \mathrm{H}, \mathrm{H}_{6}\right), 8.22\left(\mathrm{~d}_{\mathrm{br}} J=1.6 \mathrm{~Hz}, 2 \mathrm{H}, \mathrm{H}_{3}\right), 7.81(\mathrm{~s}, 4 \mathrm{H}$, $\left.\mathrm{H}_{10}\right), 7.61\left(\mathrm{t}, J=7.8 \mathrm{~Hz}, 4 \mathrm{H}, \mathrm{H}_{14}\right), 7.45\left(\mathrm{~d}, J=7.8 \mathrm{~Hz}, 8 \mathrm{H}, \mathrm{H}_{13}\right), 7.24$ $\left(\mathrm{dd}, J=5.8,1.6 \mathrm{~Hz}, 2 \mathrm{H}, \mathrm{H}_{5}\right), 2.72\left(\mathrm{t}, J=6.9 \mathrm{~Hz}, 4 \mathrm{H}, \mathrm{H}_{15}\right), 2.68(\mathrm{t}, J=$ $\left.6.9 \mathrm{~Hz}, 4 \mathrm{H}, \mathrm{H}_{15}\right), 1.39$ (d, J = 6.9 Hz, 24H, $\left.\mathrm{CH}_{3}\right), 1.27(\mathrm{~d}, J=6.9 \mathrm{~Hz}$, $\left.24 \mathrm{H}, \mathrm{CH}_{3}\right) .{ }^{13} \mathrm{C}$ NMR $\left(101 \mathrm{MHz}\right.$, acetone- $\left.\mathrm{d}_{6}\right): \delta 199.26$ (s, CO), 191.08 (s, CO), 189.94 (s, 2C, C 9 ), 156.34 (s, 2C, $\mathrm{C}_{2}$ ), 152.64 (s, 2C, $\left.\mathrm{C}_{6}\right), 148.63\left(\mathrm{~s}, 2 \mathrm{C}, \mathrm{C}_{8}\right), 146.68\left(\mathrm{~s}, 4 \mathrm{C}, \mathrm{C}_{12}\right), 139.06\left(\mathrm{~s}, 2 \mathrm{C}, \mathrm{C}_{4}\right)$, $135.40\left(\mathrm{~s}, 4 \mathrm{C}, \mathrm{C}_{11}\right), 131.41\left(\mathrm{~s}, 2 \mathrm{C}, \mathrm{C}_{14}\right), 129.78\left(\mathrm{~s}, 2 \mathrm{C}, \mathrm{C}_{5}\right), 126.91$ $\left(\mathrm{s}, 2 \mathrm{C}, \mathrm{C}_{3}\right), 125.32\left(\mathrm{~s}, 4 \mathrm{C}, \mathrm{C}_{10}\right), 125.00\left(\mathrm{~s}, 8 \mathrm{C}, \mathrm{C}_{13}\right), 101.18$ (s, 2C, $\left.\mathrm{C}_{7}\right), 24.91\left(\mathrm{~s}, 8 \mathrm{C}, \mathrm{CH}_{3}\right), 24.13\left(\mathrm{~s}, 8 \mathrm{C}, \mathrm{CH}_{3}\right) . \operatorname{IR}\left(v, \mathrm{~cm}^{-1}\right): 2111$ $(\mathrm{C} \equiv \mathrm{C}), 2016,1911,1888(\mathrm{CO}), 1603\left(\mathrm{C}_{\mathrm{Ar}}=\mathrm{N}\right)$.

Synthesis of Complex 4. To a suspension of complex 1 (40 mg, $0.078 \mathrm{mmol}$ ) and tert-butylisocyanide gold chloride $(49.5 \mathrm{mg}, 0.157$ $\mathrm{mmol})$ in $\mathrm{MeOH}(5 \mathrm{~mL})$ was added a solution of $\mathrm{KOH}(10.3 \mathrm{mg}$, $0.157 \mathrm{mmol})$ in $\mathrm{MeOH}(1 \mathrm{~mL})$, and the mixture was allowed to react for $12 \mathrm{~h}$ at room temperature. The solvent was then evaporated and the residue dissolved in DCM. After filtration over Celite, the volume was reduced to $1-2 \mathrm{~mL}$, and ether was added to precipitate complex 4 as a yellow solid (yield $64.5 \mathrm{mg}, 77 \%$ ). ${ }^{1} \mathrm{H}$ NMR (400 $\mathrm{MHz}$, $\left.\mathrm{CDCl}_{3}\right): \delta 8.81\left(\mathrm{~d}, J=5.8 \mathrm{~Hz}, 2 \mathrm{H}, \mathrm{H}_{2}\right), 8.04\left(\mathrm{~d}, J=1.6 \mathrm{~Hz}, 2 \mathrm{H}, \mathrm{H}_{5}\right)$, $7.38\left(\mathrm{dd}, J=5.8,1.6 \mathrm{~Hz}, 2 \mathrm{H}, \mathrm{H}_{3}\right), 1.60\left(\mathrm{~s}, 18 \mathrm{H}, \mathrm{H}_{11}\right) .{ }^{13} \mathrm{C}$ NMR $(101$ $\mathrm{MHz}, \mathrm{CDCl}_{3}$ ): $\delta 197.52$ (s, CO), 189.91 (s, CO), 155.37 (s, 2C, $\mathrm{C}_{6}$ ), $152.40\left(\mathrm{~s}, 2 \mathrm{C}, \mathrm{C}_{2}\right), 137.34\left(\mathrm{~s}, 2 \mathrm{C}, \mathrm{C}_{9}\right), 136.73\left(\mathrm{~s}, 2 \mathrm{C}, \mathrm{C}_{4}\right), 129.58(\mathrm{~s}$, $\left.2 \mathrm{C}, \mathrm{C}_{3}\right), 126.07$ (s, 2C, $\mathrm{C}_{5}$ ), $99.50\left(\mathrm{~s}, 2 \mathrm{C}, \mathrm{C}_{7}\right), 59.12\left(\mathrm{~s}, 2 \mathrm{C}, \mathrm{C}_{10}\right)$, $29.94\left(\mathrm{~s}, 6 \mathrm{C}, \mathrm{C}_{11}\right)$. IR $\left(\mathrm{cm}^{-1}\right): v 2984\left(\mathrm{C}_{\mathrm{sp}}{ }^{3}-\mathrm{H}\right), v 2231(\mathrm{C} \equiv \mathrm{N}), v$ $2119(\mathrm{C} \equiv \mathrm{C}), v 2016,1887(\mathrm{CO}), v 1603\left(\mathrm{C}_{\mathrm{Ar}}=\mathrm{N}\right)$.

Synthesis of Complex 5. To a stirred solution of 1 (1 equiv, 22.6 $\mathrm{mg}, 0.013 \mathrm{mmol})$ in acetonitrile $(5 \mathrm{~mL})$ was added $\mathrm{AgOTf}$ (1.1 equiv, $3.7 \mathrm{mg}, 0.014 \mathrm{mmol}$ ), and the reaction mixture was allowed to react at $40{ }^{\circ} \mathrm{C}$ overnight. The suspension was then filtrated over Celite, and the solvent was evaporated. The crude was washed with ether three times to afford an orange solid corresponding to 5 (18.4 mg, 75\%). ${ }^{1} \mathrm{H}$ NMR (400 MHz, $\mathrm{CD}_{3} \mathrm{CN}$ ): $\delta 8.64\left(\mathrm{~d}, J=5.8 \mathrm{~Hz}, 2 \mathrm{H}, \mathrm{H}_{6}\right), 8.11$ $\left(\mathrm{d}, J=1.6 \mathrm{~Hz}, 2 \mathrm{H}, \mathrm{H}_{3}\right), 7.64\left(\mathrm{t}, J=7.8 \mathrm{~Hz}, 4 \mathrm{H}, \mathrm{H}_{14}\right), 7.54(\mathrm{~s}, 4 \mathrm{H}$, $\left.\mathrm{H}_{10}\right), 7.46\left(\mathrm{~d}, J=7.8 \mathrm{~Hz}, 8 \mathrm{H}, \mathrm{H}_{13}\right), 7.28\left(\mathrm{dd}, J=5.8,1.6 \mathrm{~Hz}, 2 \mathrm{H}, \mathrm{H}_{5}\right)$, 2.62 (quint, $\left.J=6.9 \mathrm{~Hz}, 8 \mathrm{H}, \mathrm{H}_{15}\right), 2.13\left(\mathrm{~s}, 3 \mathrm{H}, \mathrm{H}_{19}\right), 1.37(\mathrm{~s}, 12 \mathrm{H}$, $\mathrm{CH}_{3}$-IPr), 1.36 (s, $\left.12 \mathrm{H}, \mathrm{CH}_{3}-\mathrm{IPr}\right), 1.29$ (s, $\left.12 \mathrm{H}, \mathrm{CH}_{3}-\mathrm{IPr}\right), 1.28(\mathrm{~s}$, $12 \mathrm{H}, \mathrm{CH}_{3}$-IPr). ${ }^{13} \mathrm{C}$ NMR (101 MHz, $\left.\mathrm{CD}_{3} \mathrm{CN}\right): \delta 189.34$ (s, 2C, $\left.\mathrm{C}_{9}\right)$ 156.58 (s, 2C, $\mathrm{C}_{2}$ ), 153.84 (s, 2C, $\mathrm{C}_{6}$ ), 148.49 (s, $\mathrm{C}_{8}$ ), 147.01 (s, 8C, $\mathrm{C}_{12}$ ), $139.47\left(\mathrm{~s}, 2 \mathrm{C}, \mathrm{C}_{4}\right), 135.17\left(\mathrm{~s}, 4 \mathrm{C}, \mathrm{C}_{11}\right), 131.66$ (s, 4C, $\mathrm{C}_{14}$ ), $130.47\left(\mathrm{~s}, 2 \mathrm{C}, \mathrm{C}_{5}\right), 127.54\left(\mathrm{~s}, 2 \mathrm{C}, \mathrm{C}_{3}\right), 125.28\left(\mathrm{~s}, 4 \mathrm{C}, \mathrm{C}_{10}\right), 125.17(\mathrm{~s}$, $\left.8 \mathrm{C}, \mathrm{C}_{13}\right), 101.68\left(\mathrm{~s}, 2 \mathrm{C}, \mathrm{C}_{7}\right), 29.63\left(\mathrm{~s}, 8 \mathrm{C}, \mathrm{C}_{15}\right), 24.82\left(\mathrm{~s}, 8 \mathrm{C}, \mathrm{CH}_{3^{-}}\right.$ IPr), 23.99 (s, 8C, $\left.\mathrm{CH}_{3}-\mathrm{IPr}\right)$. IR $\left(\mathrm{cm}^{-1}\right): v 2961\left(\mathrm{C}_{\mathrm{sp}}{ }^{3}-\mathrm{H}\right), v 2107$ $(\mathrm{C} \equiv \mathrm{C}), v$ 2032, 1917 (CO), $v 1602\left(\mathrm{C}_{\mathrm{Ar}}=\mathrm{N}\right)$. MALDI: 1643.4. Calcd M-NCCH $3: 1643.5$

Synthesis of Complex 6. To a stirred solution of 1 (1 eq, $50 \mathrm{mg}$, $0.098 \mathrm{mmol})$ in acetonitrile $(5 \mathrm{~mL})$ was added AgOTf $(1.1 \mathrm{eq}, 27.8$ $\mathrm{mg}, 0.108 \mathrm{mmol}$ ), and the reaction mixture was allowed to react overnight. The suspension was then filtrated over Celite and concentrated, and ether was added to precipitate a yellow solid corresponding to $6(49.6 \mathrm{mg}, 76 \%) .{ }^{1} \mathrm{H} \mathrm{NMR}\left(400 \mathrm{MHz}, \mathrm{CD}_{3} \mathrm{CN}\right): \delta$ $8.98\left(\mathrm{dd}, J=5.8,0.6 \mathrm{~Hz}, 1 \mathrm{H}, \mathrm{H}_{6}\right), 8.58\left(\mathrm{~d}, J=1.1 \mathrm{~Hz}, 1 \mathrm{H}, \mathrm{H}_{3}\right), 7.74$ $\left(\mathrm{dd}, J=5.8,1.6 \mathrm{~Hz}, 1 \mathrm{H}, \mathrm{H}_{5}\right), 4.16\left(\mathrm{~s}, 1 \mathrm{H}, \mathrm{H}_{8}\right), 2.05\left(\mathrm{~s}, 3 \mathrm{H}, \mathrm{H}_{10}\right) .{ }^{13} \mathrm{C}$ NMR $\left(101 \mathrm{MHz}, \mathrm{CD}_{3} \mathrm{CN}\right): \delta 156.93\left(\mathrm{~s}, \mathrm{C}_{2}\right), 155.13\left(\mathrm{~s}, \mathrm{C}_{6}\right), 135.75$ $\left(\mathrm{s}, \mathrm{C}_{4}\right), 131.28\left(\mathrm{~s}, \mathrm{C}_{5}\right), 128.14\left(\mathrm{~s}, \mathrm{C}_{3}\right), 123.68\left(\mathrm{~s}, \mathrm{C}_{9}\right), 89.28\left(\mathrm{~s}, \mathrm{C}_{8}\right)$, $79.94\left(\mathrm{~s}, \mathrm{C}_{7}\right), 3.99\left(\mathrm{~s}, \mathrm{C}_{10}\right)$. IR $\left(\mathrm{cm}^{-1}\right): v 3202\left(\mathrm{C}_{\mathrm{sp}}-\mathrm{H}\right), v 2104$ $(\mathrm{C} \equiv \mathrm{C}), v 2034,1917(\mathrm{CO}), \quad v 1609\left(\mathrm{C}_{\mathrm{Ar}}=\mathrm{N}\right)$. HRMS $(m / z)$ : $516.0341 \mathrm{M}^{+}, \mathrm{C}_{19} \mathrm{H}_{11} \mathrm{~N}_{3} \mathrm{O}_{3} \operatorname{Re}(516.0353)$

Synthesis of Complex 7. To a stirred solution of 6 ( 1 equiv, $20 \mathrm{mg}$, $0.03 \mathrm{mmol})$ in acetonitrile $(5 \mathrm{~mL})$ was added $\left[\mathrm{Au}(\mathrm{acac}) \mathrm{PPh}_{3}\right](2$ equiv, $33.6 \mathrm{mg}, 0.06 \mathrm{mmol}$ ) with a change in the color of the solution from yellow to brown. After $3 \mathrm{~h}$ of reaction, the solution was filtered over Celite and concentrated, and ether was added to precipitate a 
light brown solid corresponding to 7 (39.3 mg, 83\%). ${ }^{1} \mathrm{H}$ NMR (300 $\left.\mathrm{MHz}, \mathrm{CD}_{3} \mathrm{CN}\right): \delta 8.80\left(\mathrm{~d}, J=5.8 \mathrm{~Hz}, 2 \mathrm{H}, \mathrm{H}_{6}\right), 8.40\left(\mathrm{~s}, 2 \mathrm{H}, \mathrm{H}_{3}\right)$, $7.65-7.50\left(\mathrm{~m}, 16 \mathrm{H}, \mathrm{H}_{\mathrm{Ar}}+\mathrm{H}_{5}\right), 2.06\left(\mathrm{~s}, 3 \mathrm{H}, \mathrm{H}_{10}\right) .{ }^{13} \mathrm{C} \mathrm{NMR}(75$ $\mathrm{MHz}, \mathrm{CD}_{3} \mathrm{CN}$ ): $\delta 194.98$ (s, CO), 191.73 (s, CO), 156.88 (s, 2C, $\left.\mathrm{C}_{2}\right), 154.12\left(\mathrm{~s}, 2 \mathrm{C}, \mathrm{C}_{6}\right), 138.81$ (s, 2C, $\left.\mathrm{C}_{4}\right), 135.19$ (s, 12C, o-C, Ph), 133.08 (s, 6C, p-C, Ph), 130.86 (s, 2C, $\mathrm{C}_{5}$ ), 130.57 (s, 12C, m-C, Ph), 127.69 (s, 2C, $\mathrm{C}_{3}$ ), 123.31 (s, $\mathrm{C}_{9}$ ), 100.82 (s, 2C, $\mathrm{C}_{7}$ ), 4.14 (s, $\mathrm{C}_{10}$ ). ${ }^{31} \mathrm{P}$ NMR $\left(121 \mathrm{MHz}, \mathrm{CD}_{3} \mathrm{CN}\right): \delta 40.88(\mathrm{~s})$. IR $\left(\mathrm{cm}^{-1}\right): v 3053$ $\left(\mathrm{C}_{\mathrm{sp}}{ }^{2}-\mathrm{H}\right), v 2108(\mathrm{C} \equiv \mathrm{C}), v 2029,1905(\mathrm{CO}), v 1600\left(\mathrm{C}_{\mathrm{Ar}}=\mathrm{N}\right)$. MALDI: 1391.0. Calcd: $\mathrm{M}-\mathrm{NCCH}_{3}, 1391.1$

\section{CONCLUSIONS}

In the search for a new family of metallic-based luminescent anticancer agents that allow detection of the precise moment of interaction with the biological target, three neutral and two cationic heterotrimetallic $\operatorname{Re}(\mathrm{I}) / \mathrm{Au}(\mathrm{I})$ complexes were synthesized together with their monometallic $\operatorname{Re}(\mathrm{I})$ precursors. A key ligand, 4,4'-dialkynyl-2,2'-bipyridine $\left(\mathbf{L}_{\mathrm{NN}}\right)$, was used as a linker between the two types of metals, coordinating the rhenium atom through the nitrogen atoms in a bidentate mode and the gold atoms through the terminal alkynyl carbons. Either triphenylphosphine $\left(\mathrm{PPh}_{3}\right)$, 1,3-bis(2,6-diisopropylphenyl)-imidazol-2-ylidene (IPr), or tert-butyl isocyanide $\left(\mathrm{CN}^{\mathrm{t}} \mathrm{Bu}\right)$ was used as a gold ancillary ligand in order to modulate the luminescent and/or bioactivity of the probes. As expected, all of them are emissive in the range of $565-680 \mathrm{~nm}$, and the emission, mostly due to the $\operatorname{Re}(\mathrm{I})$ fragment, was assigned to a ${ }^{3} \mathrm{MLCT}$ transition from the $\mathrm{d} \pi(\mathrm{Re}) \rightarrow \pi^{*}\left(\mathrm{~L}_{\mathrm{NN}}\right)$. In addition, heterometallic species displayed a blue-shifted emission in comparison with that of their monometallic $\operatorname{Re}(\mathrm{I})$ counterparts. This fact could be ultimately used to monitor an interaction between $\mathbf{2}$ and $\mathbf{5}$ or $\mathbf{7}$ with a biological target, if such interaction promotes the release of the gold fragment. Crystal structures were obtained for species 1, 3, and 6, showing the expected facial disposition of the tricarbonyl ligands and confirming the bidentate character of the $\mathrm{L}_{\mathrm{NN}}$ as well as the linearity of the gold coordination mode. An antiproliferative assay in A549 (lung cancer) and $\mathrm{HeLa}$ (cervix cancer) cells revealed three important features: first, the improvement in the cytotoxicity values of the cationic species in comparison with their neutral equivalents; second, the enhancement of the toxicity over time; and finally, the general selectivity of the heterotrimetallic species toward HeLa cells with the exception of complex 3. ICP-mass spectrometry corroborated the greater cell internalization of the heterometallic cationic species. Fluorescence microscopy assays were performed to elucidate their distribution pattern and the different cytotoxic behavior in both cell lines, A549 and HeLa. The low solubility, especially that of neutral complexes, was evident using this technique, as lot of solid was randomly seen in the outside of the cells when incubated with A549. On the contrary, for the heterotrimetallic species in HeLa cells, the distribution of the complexes changed. In this case, the solid was located very close, and possibly interacting with the outer cellular membrane, which might be triggering the selectivity and higher toxicity toward the HeLa cell line over A549. Such behavior was not observed for the monometallic $\operatorname{Re}(\mathrm{I})$ complexes, suggesting a different mechanism of action. Therefore, the higher selectivity for HeLa over A549 cells displayed by heterometallic species can be associated with the gold fragment, which somehow is the main responsibility. Possibly a different composition of HeLa and A549 cell membranes makes possible such differentiation, causing the heterotrimetallic species to be more sensitive toward HeLa cell membranes. Future heterometallic probes, as in general any species designed to become drugs, should consider solubility in biological environments and targeting as one of their main features to retain. For that, alternatives such as introducing water-soluble groups or, even better, amino acid or small peptides could deliver great advantages embracing solubility and specific targeting. ${ }^{31}$

\section{ASSOCIATED CONTENT}

\section{(s) Supporting Information}

The Supporting Information is available free of charge at https://pubs.acs.org/doi/10.1021/acs.inorgchem.0c00813.

Additional figures and tables and crystallographic data (PDF)

\section{Accession Codes}

CCDC 1973254-1973256 contain the supplementary crystallographic data for this paper. These data can be obtained free of charge via www.ccdc.cam.ac.uk/data_request/cif, or by emailing data_request@ccdc.cam.ac.uk, or by contacting The Cambridge Crystallographic Data Centre, 12 Union Road, Cambridge CB2 1EZ, UK; fax: +44 1223336033.

\section{AUTHOR INFORMATION}

\section{Corresponding Authors}

Vanesa Fernández-Moreira - Departamento de Química Inorgánica, Instituto de Sintesis Química y Catálisis Homogénea (ISQCH) CSIC-Universidad de Zaragoza, 50009 Zaragoza, Spain; @orcid.org/0000-0002-1218-7218; Email: vanesa@ unizar.es

M. Concepción Gimeno - Departamento de Química Inorgánica, Instituto de Síntesis Química y Catálisis Homogénea (ISQCH) CSIC-Universidad de Zaragoza, 50009 Zaragoza, Spain; ○ orcid.org/0000-0003-0553-0695; Email: gimeno@ unizar.es

\section{Authors}

Andrés Luengo - Departamento de Química Inorgánica, Instituto de Síntesis Química y Catálisis Homogenea (ISQCH) CSIC-Universidad de Zaragoza, 50009 Zaragoza, Spain

Marta Redrado - Departamento de Química Inorgánica, Instituto de Sintesis Química y Catálisis Homogénea (ISQCH) CSIC-Universidad de Zaragoza, 50009 Zaragoza, Spain

Isabel Marzo - Departamento de Bioquímica y Biología Molecular, Universidad de Zaragoza, 50009 Zaragoza, Spain

Complete contact information is available at: https://pubs.acs.org/10.1021/acs.inorgchem.0c00813

\section{Author Contributions}

All authors have given approval to the final version of the manuscript.

Notes

The authors declare no competing financial interest.

\section{ACKNOWLEDGMENTS}

The authors thank the Ministerio de Economía y Competitividad (MINECO-FEDER CTQ2016-75816-C2-1-P), the Ministerio de Ciencia Innovación y Universidades (RTI2018097836-J-I00 and RED2018-102471-T), and Gobierno de Aragón-Fondo Social Europeo (E07_20R) for financial support. A.L. and M.R. thank the Gobierno de Aragón for a predoctoral fellowship. We are grateful to Pilar García-Orduña for her help with the refinement of the X-ray structures. 


\section{REFERENCES}

(1) Chen, K.; Chen, X. Design and development of molecular imaging probes. Curr. Top. Med. Chem. 2010, 10, 1227-1236.

(2) Fernández-Moreira, V.; Gimeno, M. C. Heterobimetallic complexes for theranostic applications. Chem. - Eur. J. 2018, 24, $3345-3353$.

(3) Wenzel, M.; de Almeida, A.; Bigaeva, E.; Kavanagh, P.; Picquet, M.; Le Gendre, P.; Bodio, E.; Casini, A. New Luminescent Polynuclear Metal Complexes with Anticancer Properties: Toward Structure-Activity Relationships. Inorg. Chem. 2016, 55, 2544-2557. (4) Boselli, L.; Carraz, M.; Mazères, S.; Paloque, L.; González, G.; Benoit-Vical, F.; Valentin, A.; Hemmert, C.; Gornitzka, H. Synthesis, structures, and biological studies of heterobimetallic $\mathrm{Au}(\mathrm{I})-\mathrm{Ru}(\mathrm{II})$ complexes involving $\mathrm{N}$-heterocyclic carbene-based multidentate ligands. Organometallics 2015, 34, 1046-1055.

(5) (a) Fernández-Moreira, V.; Thorp-Greenwood, F. L.; Coogan, M. P. Application of $\mathrm{d}^{6}$ transition metal complexes in fluorescence cell imaging. Chem. Commun. 2010, 46, 186-202. (b) Lee, L. C.-C.; Leung, K.-K.; Lo, K. K.-W. Recent development of luminescent rhenium(I) tricarbonyl polypyridine complexes as cellular imaging reagents, anticancer drugs, and antibacterial agents. Dalton Trans. 2017, 46, 16357-16380.

(6) Kumar, A.; Sun, S.-S.; Lees, A. J. Photophysics and photochemistry of organometallic rhenium diimine complexes. Photophysics of Organometallics 2009, 29, 37-71.

(7) (a) Konkankit, C. C.; King, A. P.; Knopf, K. M.; Southard, T. L.; Wilson, J. J. In Vivo Anticancer Activity of a Rhenium(I) Tricarbonyl Complex. ACS Med. Chem. Lett. 2019, 10, 822-827. (b) Knopf, K. M.; Murphy, B. L.; MacMillan, S. N.; Baskin, J. M.; Barr, M. P.; Boros, E.; Wilson, J. J. In Vitro Anticancer Activity and in Vivo Biodistribution of Rhenium(I)Tricarbonyl Aqua Complexes. J. Am. Chem. Soc. 2017, 139, 14302-14314. (c) Redshaw, C.; Watkins, S.; Humphrey, S. M.; Bulman Page, P. C.; Ashby, S.; Chao, Y.; Herbert, C. J.; Mueller, A. Rhenium(I) phenanthrolines bearing electron withdrawing $\mathrm{CF}_{3}$ substituents: synthesis, characterization and biological evaluation. RSC Adv. 2013, 3, 23963-23966.

(8) Fernández-Moreira, V.; Marzo, I.; Gimeno, M. C. Luminescent $\operatorname{Re}(\mathrm{I})$ and $\operatorname{Re}(\mathrm{I}) / \mathrm{Au}(\mathrm{I})$ complexes as cooperative partners in cell imaging and cancer therapy. Chem. Sci. 2014, 5, 4434-4446.

(9) Luengo, A.; Fernández-Moreira, V.; Marzo, I.; Gimeno, M. C. Trackable Metallodrugs Combining Luminescent $\operatorname{Re}(\mathrm{I})$ and Bioactive $\mathrm{Au}$ (I) Fragments. Inorg. Chem. 2017, 56, 15159-15170.

(10) Grosshenny, V.; Romero, F. M.; Ziessel, R. Construction of preorganized polytopic ligands via palladium-promoted cross-coupling reactions. J. Org. Chem. 1997, 62, 1491-1500.

(11) (a) Blanco, M. C.; Cámara, J.; Gimeno, M. C.; Laguna, A.; James, S. L.; Lagunas, M. C.; Villacampa, M. D. Synthesis of GoldSilver Luminescent Honeycomb Aggregates by Both Solvent-Based and Solvent-Free Methods. Angew. Chem., Int. Ed. 2012, 51, 97779779. (b) Blanco, M. C.; Cámara, J.; Gimeno, M. C.; Jones, P. G.; Laguna, A.; López-de-Luzuriaga, J. M.; Olmos, M. E.; Villacampa, M. D. Luminescent Homo- and Heteropolynuclear Gold Complexes Stabilized by a Unique Acetylide Fragment. Organometallics 2012, 31, 2597-2605.

(12) (a) Dattelbaum, D. M.; Martin, R. L.; Schoonover, J. R.; Meyer, T. J. Molecular and Electronic Structure in the Metal-to-Ligand Charge Transfer Excited States of $f a c-\left[\operatorname{Re}\left(4,4^{\prime}-\mathrm{X}_{2}\right.\right.$ bpy $)(\mathrm{CO})_{3}(4-$ Etpy $)]^{+*}\left(\mathrm{X}=\mathrm{CH}_{3}, \mathrm{H}, \mathrm{CO}_{2} \mathrm{Et}\right)$. Application of density functional theory and time-resolved infrared spectroscopy. J. Phys. Chem. A 2004, 108, 3518-3526. (b) Gonçalves, M. R.; Frin, K. P. M. Synthesis, characterization, photophysical and electrochemical properties of fac-tricarbonyl(4,7-dichloro-1,10-phenanthroline)rhenium(I) complexes. Polyhedron 2015, 97, 112-117.

(13) Wallendael, S. V.; Shaver, R. J.; Rillema, D. P.; Yoblinski, B. J.; Stathis, M.; Guarr, T. F. Ground-state and excited-state properties of monometallic and bimetallic complexes based on rhenium(I) tricarbonyl chloride: effect of an insulating vs a conducting bridge. Inorg. Chem. 1990, 29, 1761-1767.
(14) Fernández-Moreira, V.; Sastre-Martín, H. Photophysical and bioactivity behavior of $f a c$-rhenium(I) derivatives containing ditopic sulfurpyridine ligands. Inorg. Chim. Acta 2017, 460, 127-133.

(15) Yamamoto, Y.; Shiotsuka, M.; Onaka, S. Luminescent rhenium(I)-gold(I) hetero organometallics linked by ethynylphenanthrolines. J. Organomet. Chem. 2004, 689, 2905-2911.

(16) Kirgan, R. A.; Sullivan, B. P.; Rillema, D. P. Photochemistry and photophysics of coordination compounds: Rhenium. Top. Current. Chem. 2007, 281, 45-100.

(17) Pomestchenko, I. E.; Polyansky, D. E.; Castellano, F- N. Influence of a Gold(I)-Acetylide Subunit on the Photophysics of $\operatorname{Re}($ Phen $)(\mathrm{CO})_{3} \mathrm{Cl}$. Inorg. Chem. 2005, 44, 3412-3421.

(18) Yang, L.; Ren, A.-M.; Feng, J.-K.; Liu, X.-D.; Ma, Y.-G.; Zhang, H.-X. Theoretical studies of ground and excited electronic states in a series of rhenium(I) bipyridine complexes containing diarylethynylbased structure. Inorg. Chem. 2004, 43, 5961-5972.

(19) (a) Ortego, L.; Cardoso, F.; Martins, S.; Fillat, M. F.; Laguna, A.; Meireles, M.; Villacampa, M. D.; Gimeno, M. C. Strong inhibition of thioredoxin reductase by highly cytotoxic gold(I) complexes. DNA binding studies. J. Inorg. Biochem. 2014, 130, 32-37. (b) Gutiérrez, A.; Cativiela, C.; Laguna, A.; Gimeno, M. C. Bioactive gold(I) complexes with 4-mercaptoproline derivative. Dalton Trans. 2016, 45, 13483-13490. (c) Fernández-Moreira, V.; Herrera, R. P.; Gimeno, M. C. Anticancer properties of gold complexes with biologically relevant ligands. Pure Appl. Chem. 2019, 91, 247-270.

(20) (a) Liu, H.-T.; Xiong, X.-G.; Diem Dau, P.; Wang, Y.-L.; Huang, D.-L.; Li, J.; Wang, L.-S. Probing the nature of gold-carbon bonding in gold-alkynyl complexes. Nat. Commun. 2013, 4, 2223. (b) Cerrada, E.; Fernández-Moreira, V.; Gimeno, M. C. Gold and platinum alkynyl complexes for biomedical applications. Adv. Organomet. Chem. 2019, 71, 227-258.

(21) McKeage, M. J.; Berners-Price, S. J.; Galettis, P.; Bowen, R. J.; Brouwer, W.; Ding, L.; Zhuang, L.; Baguley, B. C. Role of lipophilicity in determining cellular uptake and antitumour activity of gold phosphine complexes. Cancer Chemother. Pharmacol. 2000, 46, 343350. (b)) Visbal, R.; Fernández-Moreira, V.; Marzo, I.; Laguna, A.; Gimeno, M. C. Cytotoxicity and biodistribution studies of luminescent $\mathrm{Au}(\mathrm{I})$ and $\mathrm{Ag}(\mathrm{I}) \mathrm{N}$-heterocyclic carbenes. Searching for new biological targets. Dalton Trans. 2016, 45, 15026-15033.

(22) Clède, S.; Lambert, F.; Saint-Fort, R.; Plamont, M.-A.; Bertrand, H.; Vessières, A.; Policar, C. Influence of the Side-Chain Length on the Cellular Uptake and the Cytotoxicity of Rhenium Triscarbonyl Derivatives: A Bimodal Infrared and Luminescence Quantitative Study. Chem. - Eur. J. 2014, 20, 8714-8722.

(23) Zalba, S.; ten Hagen, T. L. M. Cell membrane modulation as adjuvant in cancer therapy. Cancer Treat. Rev. 2017, 52, 48-57.

(24) Galeotti, T.; Borrello, S.; Minotti, G.; Masotti, L. Membrane alterations in cancer cells: the role of oxy radicals. Ann. N. Y. Acad. Sci. 1986, 488, 468-480.

(25) CysAlisPro, version 1.171.35.11; Agilent Technologies: Yarnton, United Kingdom.

(26) Sheldrick, G. M. Crystal structure refinement with SHELXL. Acta Crystallogr., Sect. C: Struct. Chem. 2015, 71, 3-8.

(27) Gibson, D.; Johnson, B. F. G.; Lewis, J. Metal $\beta$-diketone complexes. Part VI. Some $\beta$-diketone complexes of copper(I), silver(I), and gold(I). J. Chem. Soc. A 1970, 0, 367-369.

(28) McCleverty, J. A.; da Mota, M. M. M. Isocyanide and carbenecomplexes of gold(I). The stepwise formation of formamidines. J. Chem. Soc., Dalton Trans. 1973, 2571-2574.

(29) McAuliffe, C. A.; Parish, R. V.; Randall, P. D. Gold(I) complexes of unidentate and bidentate phosphorus-, arsenic-, antimony-, and sulphur-donor ligands. J. Chem. Soc., Dalton Trans. 1979, 1730-1735.

(30) Johnson, A.; Gimeno, M. C. An efficient and sustainable synthesis of NHC gold complexes. Chem. Commun. 2016, 52, 96649667

(31) (a) Meier-Menches, S. M.; Casini, A. Design strategies and medicinal applications of metal peptidic-bioconjugates. Bioconjugate Chem. 2020, DOI: 10.1021/acs.bioconjchem.0c00152. (b) Gutierrez, 
A.; Gimeno, M. C.; Marzo, I.; Metzler-Nolte, N. Synthesis, Characterization, and Cytotoxic Activity of AuI N,S-Heterocyclic Carbenes Derived from Peptides Containing L-Thiazolylalanine. Eur. J. Inorg. Chem. 2014, 2014, 2512-2519. 